\title{
A broadly cross-reactive monoclonal antibody against hepatitis $E$ virus capsid antigen
}

\author{
Barbara Kubickova $^{1,2} \cdot$ Jörg A. Schenk ${ }^{3,4} \cdot$ Franziska Ramm $^{5,6} \cdot$ Kornelija Markuškiené $^{1,7} \cdot$ Jochen Reetz ${ }^{8}$. \\ Paul Dremsek ${ }^{1,9}$. Paulius Lukas Tamosiunas ${ }^{7}$ - Laima Cepulyte ${ }^{7}$. Hoai Anh Trinh ${ }^{5}$. Johannes Scholz ${ }^{8}$. \\ Henry Memczak ${ }^{10}$ - Marc Hovestädt ${ }^{10,11}$ - René Ryll ${ }^{1}$. Rasa Petraityte-Burneikiene ${ }^{7}$. Victor M. Corman ${ }^{12,13}$. \\ Anika Andersson ${ }^{4,5}$. Dietmar Becher ${ }^{15}$ - Martin H. Groschup ${ }^{1,14}$. Stefan Kubick ${ }^{5,6,16}$ - Frank Sellrie ${ }^{3,4}$. \\ Reimar Johne $^{8} \cdot$ Rainer G. Ulrich ${ }^{1,14}$ (ID
}

Received: 13 December 2020 / Revised: 28 April 2021 / Accepted: 9 May 2021 / Published online: 15 June 2021

(C) The Author(s) 2021

\begin{abstract}
To generate a hepatitis E virus (HEV) genotype 3 (HEV-3)-specific monoclonal antibody (mAb), the Escherichia coli-expressed carboxy-terminal part of its capsid protein was used to immunise BALB/c mice. The immunisation resulted in the induction of HEV-specific antibodies of high titre. The mAb G117-AA4 of IgG1 isotype was obtained showing a strong reactivity with the homologous E. coli, but also yeast-expressed capsid protein of HEV-3. The mAb strongly cross-reacted with ratHEV capsid protein derivatives produced in both expression systems and weaker with an E. coli-expressed batHEV capsid protein fragment. In addition, the $\mathrm{mAb}$ reacted with capsid protein derivatives of genotypes HEV-2 and HEV-4 and common vole hepatitis $\mathrm{E}$ virus (cvHEV), produced by the cell-free synthesis in Chinese hamster ovary (CHO) and Spodoptera frugiperda (Sf21) cell lysates. Western blot and line blot reactivity of the mAb with capsid protein derivatives of HEV-1 to HEV-4, cvHEV, ratHEV and batHEV suggested a linear epitope. Use of truncated derivatives of ratHEV capsid protein in ELISA, Western blot, and a Pepscan analysis allowed to map the epitope within a partially surface-exposed region with the amino acid sequence LYTSV. The mAb was also shown to bind to human patient-derived HEV-3 from infected cell culture and to hare HEV-3 and camel HEV-7 capsid proteins from transfected cells by immunofluorescence assay. The novel $\mathrm{mAb}$ may serve as a useful tool for further investigations on the pathogenesis of HEV infections and might be used for diagnostic purposes.
\end{abstract}

\section{Key points}

- The antibody showed cross-reactivity with capsid proteins of different hepeviruses.

- The linear epitope of the antibody was mapped in a partially surface-exposed region.

- The antibody detected native HEV-3 antigen in infected mammalian cells.

Keywords Hepatitis E virus $\cdot \mathrm{HEV}-1 \cdot \mathrm{HEV}-2 \cdot \mathrm{HEV}-3 \cdot \mathrm{HEV}-4 \cdot \mathrm{HEV}-7 \cdot$ ratHEV $\cdot$ batHEV $\cdot$ cvHEV $\cdot$ Monoclonal antibody Cross-reactivity $\cdot$ Cell-free synthesis

\section{Introduction}

Hepatitis E virus (HEV) was discovered as the causative agent of acute non-A-non-B hepatitis at the beginning of the 1980s (Balayan et al. 1983). For many years, four different genotypes have been known to be involved in disease cases in

Rainer G. Ulrich rainer.ulrich@fli.de

Extended author information available on the last page of the article humans. The genotypes 1 (HEV-1) and 2 (HEV-2) were found in endemic regions with lower sanitary conditions, whereas the genotype 3 (HEV-3) was found to be distributed worldwide also affecting industrialised countries (Scobie and Dalton 2013). Genotype 4 (HEV-4) seems to have a restricted geographic distribution in Asia. Whereas HEV-1 and HEV-2 are thought to be mainly transmitted faecal-orally by contaminated water resources, the other two genotypes are zoonotic with wild boar, domesticated pig and deer representing the reservoirs (Johne et al. 2014a). Recently, further HEV genotypes, subgenotypes and strains have been identified in rabbit, 
hare, wild boar, moose, camels and other animals (Lin et al. 2015; Pavio et al. 2015; Sato et al. 2011; Schlosser et al. 2014; Takahashi et al. 2014; Woo et al. 2014; Corman et al. 2019).

In addition to human pathogenic $\mathrm{HEV}$, related viruses have been identified in fowl, rats, bats, carnivores and even in fish (Batts et al. 2011; Bodewes et al. 2013; Drexler et al. 2012; Johne et al. 2010a, b; Krog et al. 2013; Raj et al. 2012). Due to the results of experimental transmission studies, these novel viruses were initially thought to have no zoonotic potential (Johne et al. 2014a), although ratHEV-reactive antibodies have been demonstrated in forestry workers from Germany and in fever patients in China (Dremsek et al. 2012; Shimizu et al. 2016). ratHEV has been detected in rats of different species, but also in non-rodent species, i.e. shrews (Guan et al. 2013; Johne et al. 2010a; Li et al. 2013). After its initial description in Germany, ratHEV has been detected in many regions of the world suggesting a worldwide distribution (Johne et al. 2010b, 2012; Mulyanto et al. 2014; Purcell and Emerson 2008; Ryll et al. 2017; Wolf et al. 2013). Recently, several ratHEV-caused human disease cases have been reported (Andonov et al. 2019; Sridhar et al. 2018, 2021). In addition to the rat-associated HEV of genotype $\mathrm{C}$, additional hepeviruses have been discovered in rodents (Wang et al. 2017), including a virus associated to the common vole Microtus arvalis (Ryll et al. 2019).

According to the International Committee on Taxonomy of Viruses (ICTV), all these viruses belong to the family Hepeviridae (Meng et al. 2012). The family is subdivided into two genera, Orthohepevirus and Piscihepevirus (Smith et al. 2014; Walker et al. 2019), with the latter comprising only the fish-associated viruses (Batts et al. 2011). The genus Orthohepevirus comprises the human pathogenic and related genotypes within the species Orthohepevirus $A$, the avian strains as Orthohepevirus $B$, the rodent and carnivore strains as Orthohepevirus $C$ and the bat strains as Orthohepevirus D.

Hepeviruses are thought to be non-enveloped; however, membrane structures have been found to be associated with virions in a subset of cell culture-derived HEV and HEV from the serum of patients (Nagashima et al. 2014). The capsid consists of the capsid protein encoded by the open reading frame (ORF) 2. An additional, partially overlapping ORF3 encodes a small phosphoprotein which is associated with the virion and involved in virus release (Cao and Meng 2012; Zafrullah et al. 1997). The ORF1 located at the 5 '-end of the genome encodes a polyprotein comprising several nonstructural proteins including regions with similarity to methyltransferases, papain-like proteases, helicases and RNA-dependent RNA polymerases (Johne et al. 2014a) (see Fig. 1a).

The capsid protein represents the primary target for antibodies in infected individuals and therefore is the most frequently used antigen for diagnostic tests (Khudyakov and Kamili 2011). The recombinant capsid protein produced by baculovirus expression systems or yeast was found to form virus-like particles (VLPs) (Li et al. 1997, 2005a, b, 2011; Simanavicius et al. 2018). Capsid protein immunisation resulted in the induction of protective immunity in animal models (Li et al. 2004; Tsarev 1997). Furthermore, a VLPbased vaccine was developed which elicited virus-neutralising antibodies in human volunteers ( $\mathrm{Li}$ et al. 2005a). Structural and epitope mapping studies revealed that major neutralising epitopes are located within the C-terminal part of the capsid protein, forming outward-extending protrusions ( $\mathrm{P}$ domain, amino acid residues 456-606 in the case of HEV-3) (Xing et al. 1999; Yamashita et al. 2009; Zhao et al. 2015).

In the present study, we generated a novel mAb against E. coli-expressed HEV-3 capsid protein, which demonstrated a broad cross-reactivity to the capsid protein of other HEV species and strains and reacted with the native viral antigen in different test formats.

\section{Materials and methods}

\section{Construction of HEV capsid protein expression plasmids}

The construction of pET19b-mod-derived E. coli expression plasmids encoding the carboxy-terminal part of the capsid proteins (Ctr) of HEV-3, strain wbGER27 (Schielke et al. 2009) (GenBank accession number FJ705359.1), and of ratHEV strain R4 (Johne et al. 2010b) (GenBank accession number: GQ504009.1) has been described previously by Dremsek et al. 2012 (see Fig. 1b, c). Yeast-expressed ratHEV and HEV-3 capsid proteins were obtained as described previously (Simanavicius et al. 2018).

The ratHEV Ctr encoding region was further fragmented into two pieces F1 and F3 (Fig. 1c) and subcloned into pQE41 expression vector (Qiagen, Hilden, Germany) by in-fusion cloning (In-Fusion HD Cloning Kit, Clontech Laboratories, CA, USA) using the primers denoted in Table 1. PCR amplification of batHEV Ctr fragment F1 (Fig. 1d) was done using the strain BatHEV/BS7/GE/2009 (Drexler et al. 2012; GenBank accession number JQ001749.1) as a template. The PCR product was inserted into KpnI-linearized pQE-41 plasmid. The resulting pQE-41-derived proteins contain $\mathrm{N}$ terminal His-tags and dihydrofolate reductase (DHFR) sequences.

The inserted nucleotide sequences were confirmed by sequencing using the BigDye ${ }^{\circledR}$ Terminator v1.1 Cycle Sequencing Kit (Life Technologies, Carlsbad, CA, USA) and primers pQE-insert fw and pQE-insert rev (Table 1) on a 3130xl Genetic Analyser (Applied Biosystems ${ }^{\circledR}$, Life Technologies GmbH, Darmstadt, Germany).

The codon-optimized entire capsid protein coding sequence of hare HEV-3 (GenBank accession number 


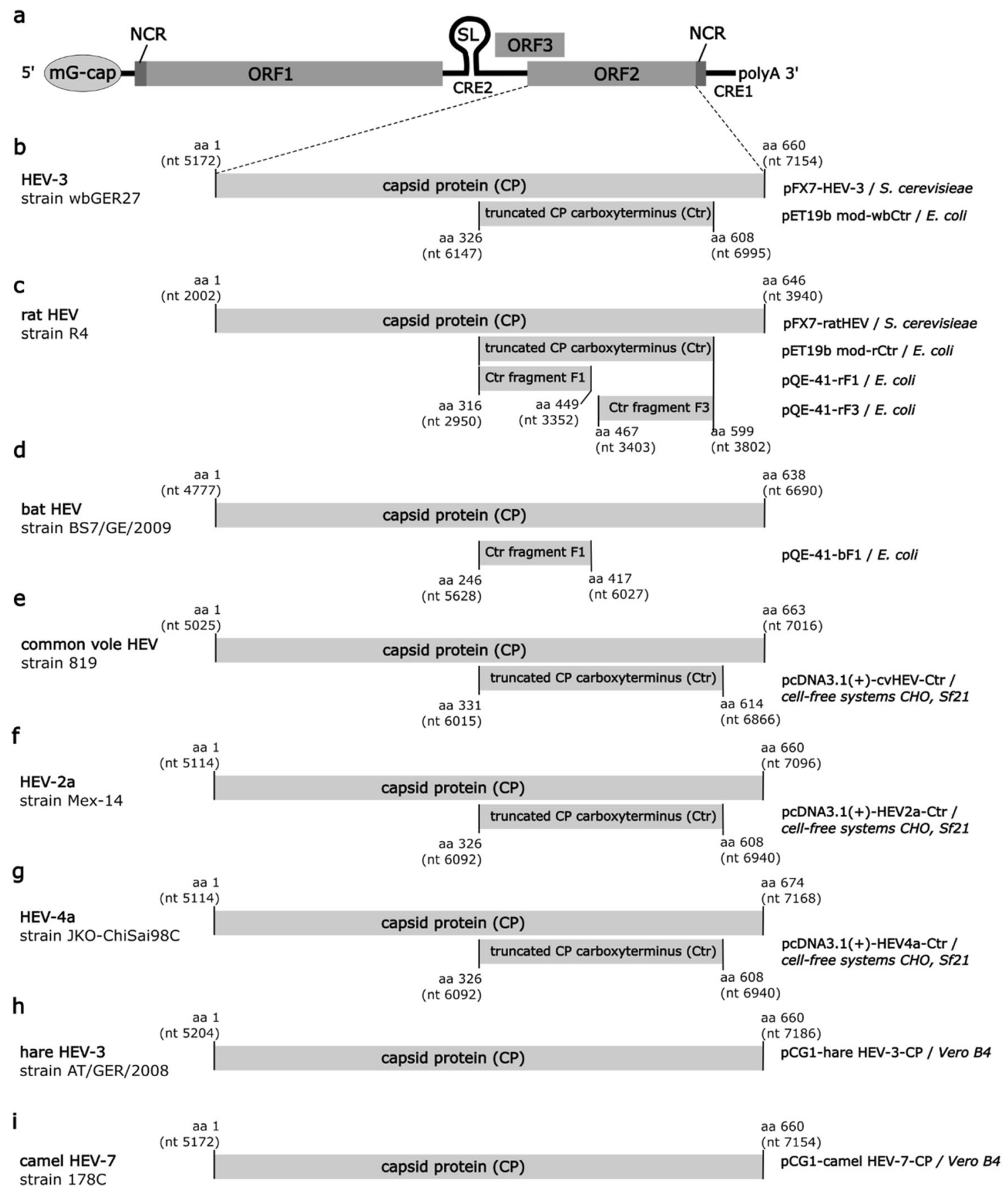

Fig. 1 Genome organization of hepatitis E virus (HEV) (a) and schematic structure of the capsid proteins of HEV-3 (b), ratHEV (c), batHEV (d), common vole HEV (e), HEV-2a (f), HEV-4a (g), hare HEV-3 (h) and camel HEV-7 (i). Corresponding expression vectors and expression systems are indicated on the right. GenBank accession numbers: HEV3 wbGER27, FJ705359.1; rat HEV strain R4, GQ504009.1; batHEV strain BS7/GE/2009, JQ001749.1; cvHEV strain 819, MK192409.1; HEV-2a strain Mex-14, KX578717.1; HEV-4a strain JKO-ChiSai98C, AB197673.1; hare HEV-3 strain AT/GER/2008, MK050463.1; camel

MK050463.1) has been inserted into the eukaryotic expression plasmid pCG1 (Corman et al. 2019; Fig. 1h). The entire capsid protein coding sequence of camel-associated HEV-7
HEV-7 strain 178C, KJ496143.1. mG-cap, 7-methylguanylate cap. NCR: non-coding region. ORF: open reading frame. SL: stem-loop structure. CRE: cis-regulatory element. polyA: polyadenylate tail. aa: amino acid. nt: nucleotide. HEV-2: HEV genotype 2. HEV-3: HEV genotype 3. HEV-4: HEV genotype 4. HEV-7: HEV genotype 7. CP: capsid protein, Ctr: carboxy-terminal truncated capsid protein, $\mathrm{CHO}$ : Chinese hamster ovary, Sf21: Spodoptera frugiperda 21. Genome organization of HEV in panel a according to Cao and Meng (2012)

(GenBank accession number KJ496143.1; Fig. 1i) was inserted in the same way into this expression plasmid and confirmed by re-sequencing. 
Table 1 Sequences of primers used for construction and sequencing of HEV-3, rat HEV and bat HEV capsid protein derivatives. italic, restriction site $\mathrm{KpnI} / \mathrm{XbaI}$; bold, viral sequence

\begin{tabular}{|c|c|c|c|c|}
\hline Target & Strain & $\begin{array}{l}\text { Designation of } \\
\text { oligonucleotide }\end{array}$ & Sequence of oligonucleotide & Reference \\
\hline $\mathrm{HEV}-3$ & wbGER27 & $\begin{array}{l}\text { wbCtr } \mathrm{fw} \\
\text { wbCtr rev }\end{array}$ & $\begin{array}{l}\text { 5' }^{\prime} \text {-TATATCTAGAACAATGACAGCCCGTCATCGGCTGCGCCGCGG } \\
\text { TGCTG-3' } \\
\text { 5' -TATATCTAGATTATGCAAGAGCCGAATGTGGGGCTAAAACAAC- } 3^{\prime}\end{array}$ & $\begin{array}{l}\text { Dremsek } \\
\text { et al } \\
2012\end{array}$ \\
\hline \multirow[t]{4}{*}{ rat HEV } & R4 & $\begin{array}{l}\text { rCtr } \mathrm{fw} \\
\text { rCtr rev }\end{array}$ & $\begin{array}{l}5 \text { ' -TATA TCTAGAACAATGACAGCCCCGCATAAGATCAAGCGGCT-3' } \\
5 \text { ' -TATATCTAGATTACTGCTCAGTCGGGCTGGGGCCGATA-3' }\end{array}$ & $\begin{array}{l}\text { Dremsek } \\
\quad \text { et al } \\
\quad 2012\end{array}$ \\
\hline & & $\begin{array}{l}\text { rHE_fw_Ctr } \\
\text { rHE_re_Ctr }\end{array}$ & $\begin{array}{l}5 \text { ' -TCAGATCTGCATGCGGTACCAGCCCCGCATAAGATCAAG-3' } \\
5 \text { '-GCAGGTCGACCCGGGGTACCTTACTGCTCAGTCGGGCTGG-3' }\end{array}$ & This study \\
\hline & & rHE_re_F1 & 5 ' -GCAGGTCGACCCGGGGTACCTTAGCGAGCGGGCGCAGGG-3' & \\
\hline & & rHE_fw_F3 & 5 '-TCAGATCTGCATGCGGTACCAGAGTATGCCCAATCGCAG-3' & \\
\hline bat HEV & $\begin{array}{l}\text { batHEV/BS7/ } \\
\text { GE/2009 }\end{array}$ & $\begin{array}{l}\mathrm{bF} 1 \mathrm{fw} \\
\mathrm{bF} 1 \mathrm{rev}\end{array}$ & $\begin{array}{l}5 \text { ' -TATA GGTACCAACTCAGCACCGCCTGACCCGCGGG-3' } \\
5 \text { '-TATAGGTACCTTAACGCTTCGGGGCAGGCGCAGGTGA-3' }\end{array}$ & This study \\
\hline $\mathrm{pQE}$ & - & PQE_insert_fw & 5 '-AGGAATTGAAAGTGACACG-3' & Qiagen \\
\hline $\mathrm{pQE}$ & - & pQE_insert_rev & 5 '-ATTACTGGATCTATCAACAGG-3' & Qiagen \\
\hline
\end{tabular}

\section{Expression and purification of HEV capsid protein derivatives in E. coli}

Expression of pET19b-mod-encoded proteins of HEV-3 and ratHEV was performed in E. coli BL21(DE3) cells in LB medium with $100 \mathrm{mg} / \mathrm{l}$ ampicillin. The pQE-encoded DHFR-ratHEV and -batHEV fusion proteins were expressed in E. coli M15[pREP4] in LB medium with $100 \mathrm{mg} / \mathrm{l}$ ampicillin and $50 \mathrm{mg} / \mathrm{l} \mathrm{kanamycin} \mathrm{as} \mathrm{described} \mathrm{by} \mathrm{Dremsek} \mathrm{et} \mathrm{al.}$ (2012). Analysis for proteins of the expected size was performed by sodium dodecyl sulphate polyacrylamide gel electrophoresis (SDS-PAGE) and Coomassie Brilliant Blue staining, as well as Western blot analysis with His $\bullet$ Tag ${ }^{\circledR} \mathrm{mAb}$ (Novagen, EMD Chemicals, Merck, Darmstadt, Germany). His-tagged recombinant proteins were purified by immobilised metal affinity chromatography (Ni-NTA sepharose) under denaturing conditions according to the protocol of the manufacturer (Qiagen, Hilden, Germany). After purification, protein concentration was determined by Bradford assay (Roth, Karlsruhe, Germany) with bovine serum albumin (BSA) used as a standard.

\section{Generation of HEV-specific monoclonal antibodies and rabbit polyclonal serum}

The HEV-specific mAb was generated by hybridoma technology (Köhler and Milstein 1975). For this purpose, 10-weekold female Balb/c mice were immunised three times with E. coli-expressed HEV-3 Ctr protein. Immunisation started with $100 \mu \mathrm{g}$ recombinant protein using Freund's complete adjuvant. Booster immunisations were carried out 5 and 12 weeks after the first immunisation using $50 \mu \mathrm{g}$ purified protein without adjuvant. Four days after the final booster immunisation, electrofusion of spleen cells with myeloma cells (P3X63Ag8.653, ATCC CRL-1580) in the presence of polyethylene glycol 8000 was performed as described (Schenk et al. 2004). Selected hybrids were cultivated in RPMI 1640 medium (containing 10\% foetal calf serum (FCS), $2 \mathrm{mM}$ glutamine and $50 \mathrm{mM} \beta$-mercaptoethanol) and subcloned by limiting dilution on mouse peritoneal feeder cells. Culture supernatants of clones and subclones were tested in an indirect enzyme-linked immunosorbent assay (ELISA) for antigen binding on recombinant HEV-3 and ratHEV proteins adsorbed to microtitre plates. The class and subclass of the $\mathrm{mAb}$ were determined in another indirect ELISA. In brief, recombinant HEV-3 Ctr protein $(5 \mu \mathrm{g} / \mathrm{ml}$ in phosphate-buffered saline (PBS)) was adsorbed to a microtitre plate. After blocking with PBS/5\% neonatal calf serum (NCS, Biochrom, Berlin, Germany), the culture supernatant of the $\mathrm{mAb}$ was added to the plate. After incubation for $1 \mathrm{~h}$, biotinylated class- and subclass-specific antibodies (Serva, Heidelberg, Germany) were added, followed by streptavidinhorseradish peroxidase (HRP) conjugate. Staining was done by addition of 3,3',5,5'-tetramethylbenzidine (TMB). Reaction was stopped after $10 \mathrm{~min}$ and absorption measured at $450 \mathrm{~nm}$.

To obtain larger amounts of this antibody, hybridoma cells were adapted to serum-free medium and fermentation conditions and the antibodies were purified from culture supernatant via protein A affinity chromatography to avoid contamination with secretory leukocyte protease inhibitor (Schenk et al. 2012).

A polyclonal serum was produced by subcutaneous immunizations of a rabbit with $E$. coli-expressed and affinity chromatography purified HEV-3 Ctr capsid protein derivative (Dremsek et al. 2012). This serum has been successfully used 
in immune electron microscopy (Berto et al. 2013) and immunofluorescence assays (Johne et al. 2016; Schemmerer et al. 2016).

\section{ELISA and line assay}

Characterisation of the $\mathrm{mAb}$ was performed using a commercially available recomLine HEV assay with HEV-1 and HEV3 antigens (Mikrogen, Neuried, Germany) and in-house assays using recombinant HEV-3, ratHEV and batHEV antigens produced in E. coli. The commercial assay was performed according to the protocol of the manufacturer, except that HRP-labelled anti-mouse IgG (Blotting Grade Affinity Purified Goat Anti-Mouse IgG (H+L) HRP Conjugate, BioRad, Munich, Germany), diluted 1:2000, was used.

Antibody titrations in the in-house ELISAs were carried out following a modified protocol of Dremsek et al. (2012). Briefly, a microtitre plate (MaxiSorp, Nunc, Thermo Fisher Scientific, Waltham, MA, USA) was coated overnight at $4{ }^{\circ} \mathrm{C}$ with $100 \mu \mathrm{l}$ per well of $1.0 \mu \mathrm{g} / \mathrm{ml}$ purified recombinant antigen in carbonate buffer or plain carbonate buffer. After initial binding of the antigens, free binding sites of the plate were blocked with $200 \mu \mathrm{l} / \mathrm{well}$ of $1.0 \%$ (w/v) BSA in PBS with $0.05 \%$ Tween $20(0.05 \%$ PBS-T) for $1 \mathrm{~h}$ at room temperature. The blocking buffer was then replaced by $100 \mu$ primary antibody in binding buffer $(0.5 \%$ (w/v) BSA in $0.05 \%$ PBS$\mathrm{T}$ ) and incubated for $1 \mathrm{~h}$ at $37{ }^{\circ} \mathrm{C}$. Each well was subsequently washed three times with $250 \mu \mathrm{l} 0.1 \%$ PBS-T and incubated for $1 \mathrm{~h}$ at $37^{\circ} \mathrm{C}$ with $100 \mu \mathrm{l}$ of HRP-coupled secondary antibody (Blotting Grade Affinity Purified Goat Anti-Mouse IgG $(\mathrm{H}+\mathrm{L})$ HRP Conjugate, Bio-Rad), diluted 1:5000 in binding buffer. Before application of the peroxidase substrate TMB (Bio-Rad) with $100 \mu \mathrm{l} /$ well, the plate was washed three times with $250 \mu \mathrm{l} 0.1 \%$ PBS-T per well. The chromogenic reaction of TMB with HRP was carried out for $10 \mathrm{~min}$ at room temperature in the dark, before being stopped by addition of $100 \mu 11 \mathrm{M}$ sulphuric acid per well. For quantification of the colour reaction, the absorbance at $450 \mathrm{~nm}$ was determined on a microtitre plate reader (Infinite M200 Pro, Tecan, Salzburg, Austria). Data were evaluated in Excel 2007 (Microsoft Office), and non-linear regression with least-squares fit to obtain $\mathrm{EC}_{50}$-values as a parameter of antigen-binding was performed using GraphPad Prism (v. 5.00 for Windows, GraphPad Software, San Diego California USA, www. graphpad.com).

\section{SDS-PAGE and Western blot analysis}

For Western blot analysis, purified recombinant proteins $(1 \mu \mathrm{g}$ protein/lane) of HEV-3, ratHEV and batHEV or persistently HEV-3-infected cells were separated by discontinuous denaturing SDS-PAGE (Green and Sambrook 2012).
After transfer of the proteins onto a polyvinylidenfluoride (PVDF) membrane (Immobillon P, EMD Millipore, Billerica, MA, USA) by semidry Western blotting for 90 min at $20 \mathrm{~V}$ and $0.18 \mathrm{~mA}$ per $\mathrm{cm}^{2}$ of gel size, free binding sites were blocked with $5 \%(\mathrm{w} / \mathrm{v})$ skim milk in $0.1 \%$ PBS-T at $4{ }^{\circ} \mathrm{C}$ overnight. Incubation with primary antibody (mAb G117AA4: $0.25 \mu \mathrm{g} / \mathrm{ml}$; mouse anti-human- $\beta$-actin antibody (8H10D10, Cell Signaling, Beverly, MA, USA): 1:10,000) was carried out in blocking buffer for $1 \mathrm{~h}$, gently agitating at room temperature, followed by three washing steps with $10 \mathrm{ml}$ PBS-T for $10 \mathrm{~min}$. HRP-coupled secondary antibody (Blotting Grade Affinity Purified Goat Anti-Mouse IgG (H+ L) HRP Conjugate, Bio-Rad) was diluted 1:2000 in 0.1\% PBS-T and incubated gently agitated at room temperature for $1 \mathrm{~h}$. Subsequently, the membrane was washed twice with $10 \mathrm{ml} 0.1 \%$ PBS-T for $10 \mathrm{~min}$ and twice with $10 \mathrm{ml}$ PBS for $10 \mathrm{~min}$, before the peroxidase substrate was applied to the membrane. Chemiluminescence using Pierce ECL Western Blotting Substrate (Thermo Fisher Scientific, Waltham, MA, USA) was detected in a VersaDoc 400MP (Bio-Rad) with an exposure time of $120 \mathrm{~s}$.

\section{Cell-free synthesis of ORF2-encoded proteins of CVHEV, HEV-2 and HEV-4}

Cell-free synthesis reactions using translationally active lysates derived from Chinese hamster ovary $(\mathrm{CHO})$ cells and Spodoptera frugiperda 21 (Sf21) cells were performed as previously described (Brödel et al. 2013, 2014; Stech et al. 2012; Thoring et al. 2016). Plasmids encoding the $\mathrm{C}$-terminal region of the cvHEV strain 11_819 (GenBank accession number MK192409) capsid protein (Fig. 1e) were designed according to Brödel et al. (2013). In this study, two plasmids were used: one harbouring the coding gene sequence alone and a second plasmid encoding an additional melittin (Mel) signal sequence at the N-terminus of the capsid protein. The Mel-signal sequence was used to facilitate the translocation of the cvHEV protein into the microsomal vesicles present in the eukaryotic lysate. Hence, possible glycosylation patterns of the protein could be analysed. Genes were obtained by de novo gene synthesis (BioCat $\mathrm{GmbH})$. Sequences were cloned into the pcDNA3.1(+) vector backbone by BioCat $\mathrm{GmbH}$, and the plasmids were directly used as a template in cell-free protein synthesis. In a further evaluation, gene fragments of HEV-2a (GenBank accession number KX578717.1, amino acid residues 326-608) and HEV-4a (GenBank accession number AB197673.1, amino acid residues 326-608) were tested in eukaryotic cell-free systems. Therefore, gene blocks generated by Integrated DNA Technologies IDT (Coralville, IA, USA) harbouring the Mel signal peptide were used for cell-free protein synthesis (see Fig. 1f and 1g).

Protein synthesis was conducted in coupled transcription/ translation reactions in a final volume of $25 \mu \mathrm{l}$ using either 
CHO or $S f 21$ lysate. Batch-based reactions were incubated in a thermomixer (Eppendorf, Hamburg, Germany) for $3 \mathrm{~h}$ at 30 ${ }^{\circ} \mathrm{C}(\mathrm{CHO})$ or $27{ }^{\circ} \mathrm{C}(\mathrm{Sf2} 1)$ and $500 \mathrm{rpm}$. Cell-free synthesis reactions were composed of $40 \%(\mathrm{v} / \mathrm{v})$ translationally active lysate supplemented with HEPES-KOH (30 mM, pH 7.6, Carl Roth GmbH, Karlsruhe, Germany), sodium acetate $(100 \mathrm{mM}$, Merck, Darmstadt, Germany), $\mathrm{Mg}(\mathrm{OAc})_{2}$ (3.9 mM, Merck), KOAc (150 mM, Merck), amino acids (complete $100 \mu \mathrm{M}$, Merck), spermidine (0.25 mM; Roche) and energy regenerating components including creatine phosphokinase (0.1 mg/ml, Roche), creatine phosphate (20 mM, Roche), ATP (1.75 mM, Roche) and GTP (0.3 mM, Roche), $1 \mathrm{U} / \mu \mathrm{l}$ T7 RNA polymerase, $0.3 \mathrm{mM}$ of UTP (Roche), CTP (Roche) and $0.1 \mathrm{mM}$ of the cap analogue m7G(ppp)G (Prof. Edward Darzynkiewicz, Warsaw University, Poland). PolyG primer (12 $\mu \mathrm{M}$, IBA) was additionally supplemented. For further analyses including autoradiography, cell-free protein synthesis reactions were supplemented with radioactive ${ }^{14} \mathrm{C}$-leucine (50 $\mathrm{\mu M}$, specific radioactivity $66.67 \mathrm{dpm} / \mathrm{pmol}$, Perkin Elmer).

After $3 \mathrm{~h}$ of incubation, the crude translation mixture (TM) was centrifuged $\left(16,000 \times \mathrm{g}, 10 \mathrm{~min}, 4{ }^{\circ} \mathrm{C}\right)$ resulting in the supernatant $(\mathrm{SN})$ containing the soluble proteins that were synthesised without Mel-signal sequence and the pelleted microsomes containing the translocated proteins harbouring a Mel-signal peptide. The pellet was resuspended in PBS resulting in the microsomal fraction (MF).

\section{Western blot analysis of proteins produced by cell- free synthesis}

For qualitative analysis, the SN fraction of proteins without Mel-signal peptide and the MF of proteins with Mel-signal peptide were analysed. Protein samples were analysed in native and denatured form. To study the binding of the G117AA4 antibody to native proteins, $10 \mu \mathrm{l}$ of SN or MF were mixed with $10 \mu$ l of $2 \times$ LDS sample buffer (NUPAGE LDS sample buffer) and directly loaded onto the gel. Further, $10 \mu \mathrm{l}$ aliquots of the fraction of interest were precipitated in cold acetone (Carl Roth $\mathrm{GmbH}$ ) and handled as described previously (Thoring et al. 2019). SDS-PAGE using precast (NuPAGE, 10\% Bis-Tris, Life technologies) and self-cast (10\% Tris-Glycine, Life technologies) were performed. SeeBlue Plus2 Pre-Stained marker was used as a weight measurement. Afterwards, Western blotting was performed using the iBlot Gel transfer device. Proteins were blotted on a PVDF membrane with $20 \mathrm{~V}$ for $10 \mathrm{~min}$. The membranes were washed with TBS/T for $5 \mathrm{~min}$, repeated twice and incubated overnight at $4{ }^{\circ} \mathrm{C}$ with blocking buffer $(2 \%$ BSA in $\mathrm{TBS} / \mathrm{T})$. On the next day, three washing steps with TBS/T were implemented before incubating the membrane with antibody G117-AA4 (1:1000, 2\% BSA in TBS/T) or the polyclonal rabbit serum (see above) for $3 \mathrm{~h}$ at room temperature on an orbital shaker at $60 \mathrm{rpm}$. The washing procedure in TBS/T was repeated, followed by addition of the secondary HRPlinked anti-mouse IgG antibody $(1: 2000,2 \%$ BSA in TBS/ T, Cell Signalling Technologies, Beverly, MA, USA) for the monoclonal antibody and a HRP-linked anti-rabbit antibody (1:1000, 2\% BSA in TBS/T, Cell Signalling Technologies) for the polyclonal rabbit serum, and incubation of the membrane for $1 \mathrm{~h}$. After a final washing procedure, the membranes were incubated with a chromogenic 4-chloro-1-naphtol/ $\mathrm{MeOH} / \mathrm{PBS} / \mathrm{H}_{2} \mathrm{O}_{2}$ solution to visualize the immune reaction for the initial Western blot analysis of cvHEV-derived capsid protein derivatives. The immune reaction of cvHEV, HEV-2a and HEV-4a capsid proteins was visualized with chemiluminescent WesternBright ECL HRP substrate (Advanstra, San Jose, CA, USA) and detected with the Azure c600 Gel Imaging System (Azure Biosystems, Dublin, CA, USA). At last, the membranes were dried at $70{ }^{\circ} \mathrm{C}$ (Unigeldryer 3545D, Uniequip, Planegg, Germany), placed on a phosphor screen (GE Healthcare, Freiburg, Germany) and radioactively labelled proteins were visualised using a Typhoon Trio + variable mode imager (GE Healthcare).

\section{Cell culture propagation of HEV-3}

The HEV-3 strain 47832c was originally isolated from the serum of a chronically infected transplant patient by inoculation onto the human lung carcinoma cell line A549 (ATCCCCL-185 $\left.{ }^{\mathrm{TM}}\right)$. By this, a cell line persistently infected with the HEV strain was established (Johne et al. 2014b). These cells were seeded and grown for 14 days as described (Schemmerer et al. 2016), and subsequently analysed by immunofluorescence and Western blot assays. Non-infected A549 cells served as control.

\section{Immunofluorescence analysis}

Persistently HEV-3-infected A549 cells and non-infected A549 cells were fixed using acetone/methanol (1:1) after growth for 14 days at $34.5^{\circ} \mathrm{C}$ in 24 -well tissue culture plates. After washing with PBS, cells were treated with $1 \mathrm{ml}$ PBS supplemented with $1 \% \mathrm{FCS}$ for $10 \mathrm{~min}$ at $37{ }^{\circ} \mathrm{C}$. After that, $100 \mu \mathrm{PBS}$ supplemented with $1 \%$ FCS and containing the antibody G117-AA4 in a dilution of 1:100 (corresponding to $0.66 \mu \mathrm{g}$ ) were added. After incubation for $1 \mathrm{~h}$ at $37^{\circ} \mathrm{C}$, cells were washed three times with PBS and $100 \mu$ l of anti-mouse IgG-fluorescein isothiocyanate conjugate (Sigma, Deisenhofen, Germany), diluted 1:200 in PBS with 1\% FCS was added. After further incubation for $1 \mathrm{~h}$ at $37^{\circ} \mathrm{C}$, cells were washed twice with PBS and once with double-distilled water and mounted using Roti®-Mount Fluor Care DAPI (Carl Roth $\mathrm{GmbH}$, Karlsruhe, Germany). Fluorescence was observed under an Axio Observer Z1 microscope (Carl Zeiss Microscopy 
GmbH, Jena, Germany). By this, HEV antigen shows green fluorescence, whereas the cell nuclei are stained in blue.

For analysis of the capsid proteins of hare HEV-3 and camel HEV-7, Vero B4 cells were transfected by the corresponding pCG1-derived expression plasmids. Immunofluorescence analyses with mAb G117-AA4 was performed essentially as described previously (Corman et al. 2019), but stained with Alexa 488-labeled anti-mouse IgG. The mAb was used in a dilution of $1: 100$.

\section{Pepscan analysis}

Epitope mapping with the protein sequence of the F1fragment of ratHEV was performed using surface-based peptide synthesis, following an adapted $\mathrm{F}_{\text {moc }}$-based peptide synthesis protocol (Frank 1992) to generate the microarray with an automated spotting robot (Slide Spotting Robot, Intavis Bioanalytical Instruments AG, Cologne, Germany). The synthesis was performed on amino-modified glass slides, followed by primary antibody G117-AA4 incubation at $50 \mathrm{nM}$ in PBS-T buffer for several hours or overnight. Subsequently, after washing, secondary Alexa Fluor 647-labelled goat anti-mouse antibody (115-605-071, Jackson ImmunoResearch Laboratories, Inc., West Grove, PA, USA) was incubated for $2 \mathrm{~h}$ at $750 \mathrm{ng} / \mathrm{ml}$. After washing and drying, the fluorescence signal was detected using a GenePix Axon 4000A (Molecular Devices, Sunnyvale, CA, USA) fluorescence scanner.

\section{Amino acid sequence comparison}

Amino acid sequences were obtained by in silico translation of ORF2 nucleotide sequences of HEV-3, strain wbGer27, ratHEV strains R4 and R63, batHEV strain BS7 GE 2009, cvHEV strain 11_819/CZE/2010, HEV-1, HEV-2, HEV-4, hare $\mathrm{HEV}-3$, camel HEV-7 and additional reference sequences of Orthohepevirus $A$ and Orthohepevirus $C$ genotypes (Smith et al. 2014, 2016, 2020) (GenBank accession numbers are given in Table 2). The resulting amino acid sequences were aligned using ClustalW algorithm in BioEdit software (version 7.0.5, www.mbio.ncsu.edu/BioEdit/ bioedit.htm).

\section{Results}

\section{Generation and initial characterisation of a HEV-3- specific monoclonal antibody}

Immunisation of two mice with recombinant HEV-3 Ctr protein expressed in $E$. coli led to an ELISA titre ranging from $1: 10,000$ to $1: 20,000$. The electrofusion of spleen cells with myeloma cell line P3X63Ag8.653 yielded in more than 1000 hybridoma clones of which 12 clones reacted in the ELISA with $E$. coli-expressed HEV-3 Ctr protein as antigen. Clone G117-AA4 was eventually established as a monoclonal cell line and chosen for further investigations. The isotype of the antibody was determined as IgG1. Initial analysis of the clone G117-AA4 confirmed its reactivity with the HEV-3 Ctr antigen in ELISA and Western blot analyses (data not shown). In addition to the $E$. coli-expressed HEV-3 Ctr protein, the antibody also detected the corresponding yeast-expressed Ctr protein derivative in both test formats. In addition, the $\mathrm{mAb}$ reacted with the $\mathrm{O} 2 \mathrm{C}$ antigens of $\mathrm{HEV}-3$ and $\mathrm{HEV}-1$ in the recomLine assay (Figure $\mathrm{S} 1$ ). In parallel, human sera were used as negative and positive controls in this line assay.

\section{Reactivity of the mAb G117-AA4 with HEV-3, ratHEV and batHEV capsid protein derivatives}

Clone G117-AA4 showed a strong cross-reactivity to the recombinant $E$. coli-expressed ratHEV and HEV-3 capsid protein derivatives in ELISA (Figure S2). The strong crossreactivity was confirmed by Western blot analyses (Fig. 2), resulting in similar band intensity of ratHEV-Ctr and HEV-3Ctr. Besides the detection of these two E. coli-expressed recombinant capsid protein derivatives, mAb G117-AA4 successfully detected multiple bands in full-length yeastexpressed ratHEV and HEV-3 capsid proteins. ratHEV and batHEV, for which $E$. coli-expressed recombinant DHFR fusions of Ctr fragments exist (F1 and F3, see Fig. 1c/d), exhibited detection signals exclusively with the F1 part of the protein corresponding to the amino acid residues 316 to 449 . The DHFR-F3 constructs of ratHEV did not show any reactivity (Fig. 2). These results were also confirmed by ELISA (data not shown).

\section{Cross-reactivity of G117-AA4 with cell-free produced capsid protein derivatives}

The cvHEV C-terminal region of capsid protein was synthesised in $\mathrm{CHO}$ as well as $S f 21$ lysates and binding of antibody G117-AA4 was analysed. To characterise the antibody binding, native as well as precipitated protein fractions were analysed. Figure 3 a shows the binding of the G117-AA4 antibody to the cvHEV C-terminal region of capsid protein expressed in both lysates, $\mathrm{CHO}$ as well as $S f 21$. Further, both native and precipitated proteins could be detected. cvHEV protein harbouring a Mel-signal sequence synthesised in a Sf21 lysate showed additional bands that suggested the glycosylation of the protein. To match the blotted protein bands to synthesised radioactively labelled protein, the blot was visualised via autoradiography. Protein bands in the autoradiograph correspond to the blotted proteins (Fig. 3b). The autoradiograph further indicates the glycosylation of cvHEV protein in a $S f 21$ cell-free expression system when using a 
Table 2 Multiple sequence alignment of the assumed G117-AA4 epitope region of different HEV genotypes. The amino acid sequence NGEPSVKLYTSVEAA (shaded, blue) showed very high affinity to
mAb G117-AA4 in Pepscan analysis with the peptide LYTSV (shaded, red) being the major epitope region. CTR_swineHEV_wbGER27 FJ705359 (bold) was used for generation of $\mathrm{mAb}$ G117-AA 4

\section{CTR_swineHEV_wbGER27_FJ705359}

CTR_ratHEV_R4-Isolate_GQ504009.1

CTR_ratHEV_R63_GU345042

CTR_batHEV_BS7_GE_2009_JQ001749

CTR_common_voleHEV_11_819/CZE/2010_Mwand92409.1

HEV_genotype_1a_Burma_M73218

HEV_genotype_1b_Xinjiang_L08816

HEV genotype 1c 11 X98292

HEV_genotype_1d_Morocco_AY2302

HEV_genotype_1e_T3_AY204877

HEV_genotype_1f_IND-HEV-AVH5-2010_JF443721

HEV_genotype_1g_MNE15-072_LC225387

HEV_genotype_1_HEV-H_FJ457024

HEV_genotype_1_NG/17-0503_MH918640

HEV_genotype_2a_Mex-14_KX578717

HEV_genotype_2b_MG/17-0500_MH809516

HEV_genotype_3_WB/HEV/NA21ITA15_MF959765

HEV_genotype_3_swHE1606845_LC260517

HEV_genotype_3_17RS1920_MK390971

HEV_genotype_3_WB/HEV/NA17ITA15_MF959764

HEV_genotype_3_MWP_2010_KP294371

HEV_genotype_3_swMN06-C1056_AB290313

HEV_genotype_3_W1-11_JQ013791

HEV_genotype_3a_Meng_AF082843

HEV_genotype_3b_JRA1_AP003430

HEV_genotype_3c_wbGER27_FJ7053

HEV_genotype_3e_swJ8-5_AB24852

HEV_genotype_3f_E116-YKH98C_AB369687

HEV_genotype_3g_Osh_205_AF4557

HEV_genotype_3h_TR19_JQ013794

HEV_genotype_3i_BB02_FJ998008

HEV_genotype_3j_Arkell_AY11548

HEV_genotype_3k_E088-STM04C_AB369689

HEV_genotype_3l_FR-SHEV3c-like_JQ953664

HEV_genotype_3m_IC2011_KU513561

HEV_genotype_3ra_GDC9_FJ906895

HEV_genotype_3ra_RabbitHEV_W1-11_JQ013791

HEV_genotype_3ra_Rabbit/HumanHEV_TLS-18516_JQ013793 HEV_genotype_4_E087-SAP04C_AB369688

HEV_genotype_4_SWU/42-5/2018_MK410048

HEV_genotype_4a_JKO-ChiSai98C_AB197673

HEV_genotype_4b_swDQ_DQ279091

HEV_genotype_4c_JAK-Sai_AB0749

HEV_genotype_4d_T1_AJ272108

HEV_genotype_4e_IND-SW-00-01_AY723745

HEV_genotype_4f_HE-JA2_AB22097

HEV_genotype_49_CCC220_AB10853

HEV_genotype_4h_CHN-XJ-SW13_GU119961

HEV_genotype_4i_E067-SIJ05C_AB369690

HEV_genotype_5a_JBOAR135-Shiz09_AB573435

HEV_genotype_6_wbJNN_13_AB856243

HEV_genotype_6a_wbJOY_06_AB602441

HEV_genotype_7_180C_KJ496144

HEV_genotype_7a_178C_KJ496143

HEV_genotype_8_BcHEV-GP_MH410174

HEV_genotype_8a_12XJ_KX387865

HEV_genotype_FerretHEV_JN998606

HEV_genotype_HareHEV_MK050463

HEV_genotype_AvianHEV_AY535004

HEV_genotype_AvianHEV_GU954430

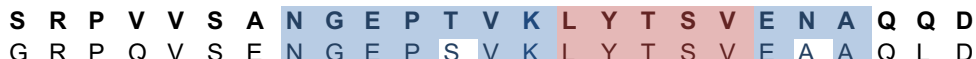

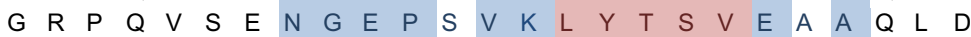

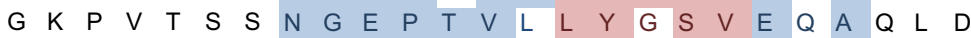

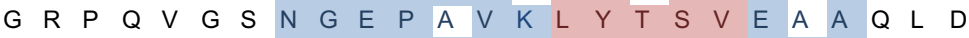


$\begin{array}{lllllllllllllllllllllllll}S & R & P & V & V & S & A & N & G & E & P & T & V & K & L & Y & T & S & V & E & N & A & Q & Q & D\end{array}$

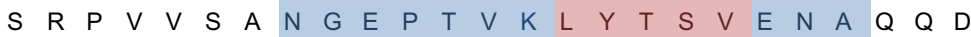

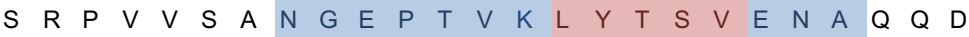

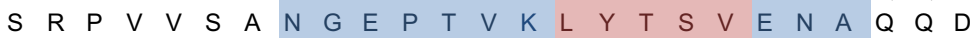
$\begin{array}{lllllllllllllllllllllllll}S & R & P & V & V & S & A & N & G & E & P & T & V & K & L & Y & T & S & V & E & N & A & Q & Q & D\end{array}$

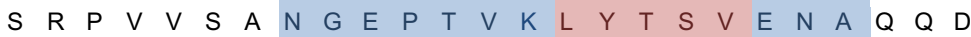
$\begin{array}{lllllllllllllllllllllllll}S & R & P & V & V & S & A & N & G & E & P & T & V & K & L & Y & T & S & V & E & N & A & Q & Q & D\end{array}$

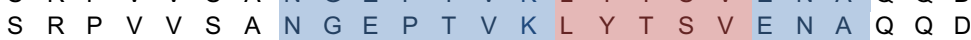

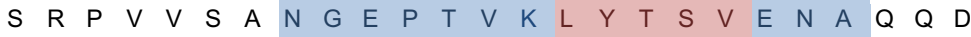

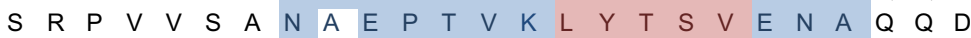

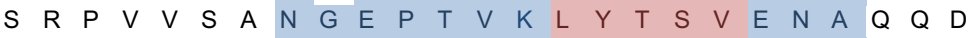

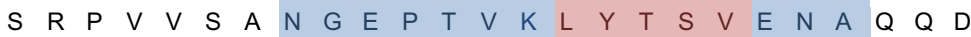
$\begin{array}{lllllllllllllllllllllllll}S & R & P & V & V & S & A & N & G & E & P & T & V & K & L & Y & T & S & V & E & N & A & Q & Q & D\end{array}$

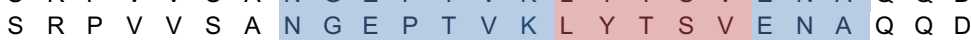
$\begin{array}{lllllllllllllllllllllllll}S & R & P & V & V & S & A & N & G & E & P & T & V & K & L & Y & T & S & V & E & N & A & Q & Q & D\end{array}$

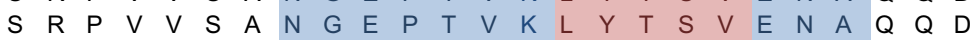

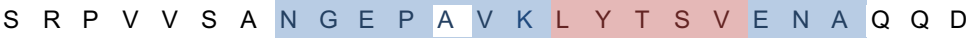

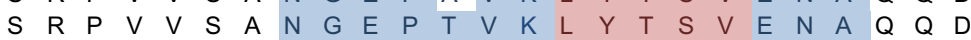
$\begin{array}{lllllllllllllllllllllllll}S & R & P & V & V & S & A & N & G & E & P & T & V & K & L & Y & T & S & V & E & N & A & Q & Q & D\end{array}$

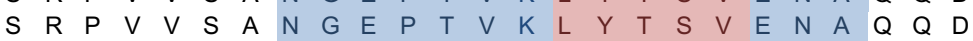

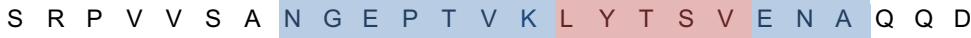

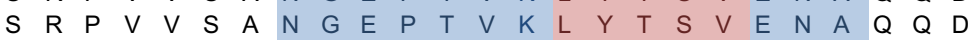

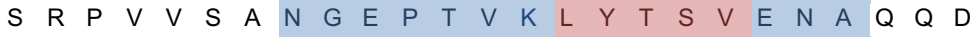

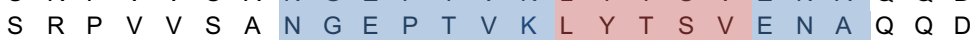
$\begin{array}{lllllllllllllllllllllllll}S & R & P & V & V & S & A & N & G & E & P & T & V & K & L & Y & T & S & V & E & N & A & Q & Q & D\end{array}$

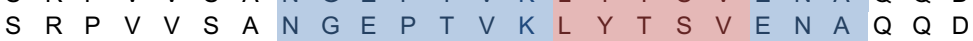

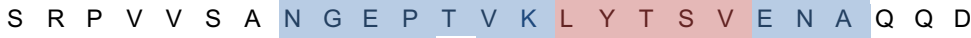

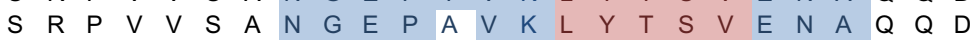
$\begin{array}{lllllllllllllllllllllllll}S & R & P & V & V & S & A & N & G & E & P & T & V & K & L & Y & T & S & V & E & N & A & Q & Q & D\end{array}$

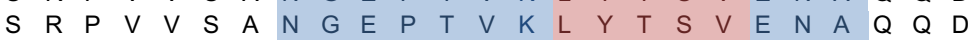

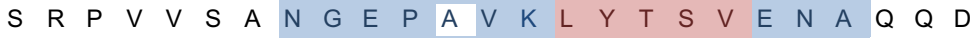

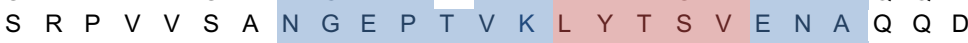
$\begin{array}{lllllllllllllllllllllllll}S & R & P & V & V & S & A & N & G & E & P & T & V & K & L & Y & T & S & V & E & N & A & Q & Q & D\end{array}$

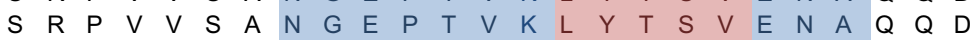
$\begin{array}{lllllllllllllllllllllllll}S & R & P & V & V & S & A & N & G & E & P & T & V & K & L & Y & T & S & V & E & N & A & Q & Q & D\end{array}$

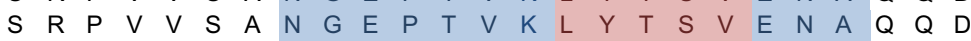
$\begin{array}{lllllllllllllllllllllllll}S & R & P & V & V & S & A & N & G & E & P & T & V & K & L & Y & T & S & V & E & N & A & Q & Q & D\end{array}$

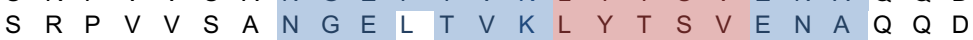
$\begin{array}{llllllllllllllllllllllllll}S & R & P & V & V & S & A & N & G & E & P & T & V & K & L & Y & T & S & V & E & N & A & Q & Q & D\end{array}$

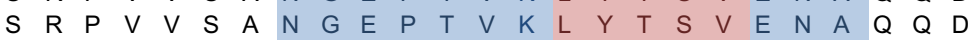
$\begin{array}{llllllllllllllllllllllllll}S & R & P & V & V & S & A & N & G & E & P & T & V & K & L & Y & T & S & V & E & N & A & Q & Q & D\end{array}$


$\begin{array}{llllllllllllllllllllllllll}S & R & P & V & V & S & A & N & G & E & P & T & V & K & L & Y & T & S & V & E & N & A & Q & Q & D\end{array}$

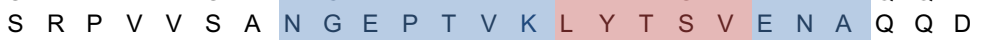
$\begin{array}{llllllllllllllllllllllllll}S & R & P & V & V & S & A & N & G & E & P & T & I & K & L & Y & T & S & V & E & N & A & Q & Q & D\end{array}$

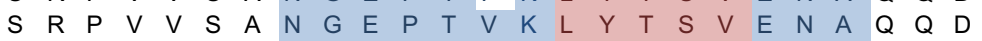
$\begin{array}{llllllllllllllllllllllllll}S & R & P & V & V & S & A & N & G & E & P & S & V & K & L & Y & T & S & V & E & N & A & Q & Q & D\end{array}$ $\begin{array}{llllllllllllllllllllllllll}S & R & P & V & V & S & A & N & G & E & P & S & V & K & L & Y & T & S & V & E & N & A & Q & Q & D\end{array}$ $\begin{array}{llllllllllllllllllllllllll}S & R & P & V & V & S & A & N & G & E & P & T & V & K & L & Y & T & S & V & E & N & A & Q & Q & D\end{array}$

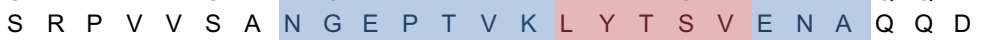
$\begin{array}{llllllllllllllllllllllllll}G & R & P & Q & V & S & A & N & G & E & P & S & V & K & L & Y & T & S & V & E & A & A & Q & L & D\end{array}$ $\begin{array}{lllllllllllllllllllllllll}S & R & P & V & V & S & A & N & G & E & P & T & V & K & L & Y & T & S & V & E & N & A & Q & Q & D\end{array}$

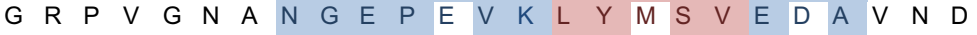
$G R P \vee G N A N G E P E V K L Y M S V E D A V N D$
Mel-signal sequence. In a next step, coding sequences for HEV-2a and HEV-44a capsid protein fragments with a Melsignal peptide were synthesized in $\mathrm{CHO}$ and $S f 21$ lysates in comparison to the cvHEV capsid protein fragment. Figure $3 \mathrm{c}$ shows the specific binding of the G117-AA4 antibody to all three HEV protein products synthesized in both $\mathrm{CHO}$ and 


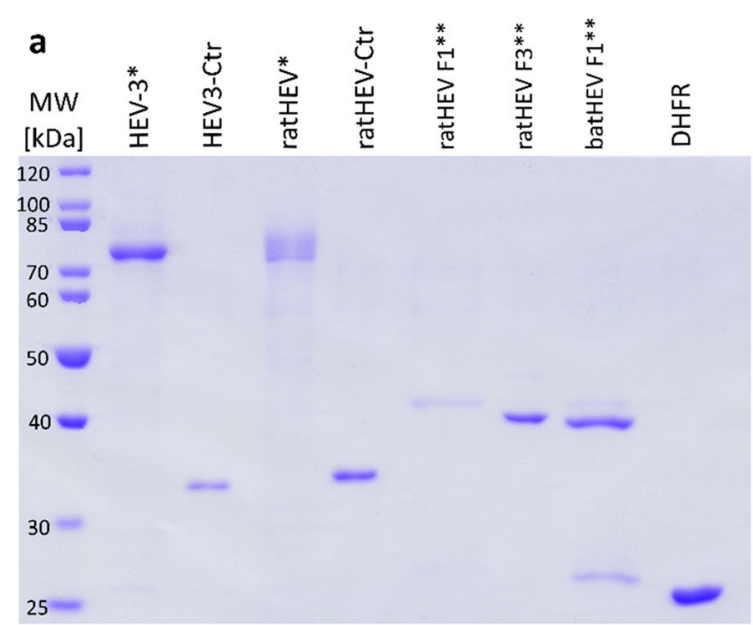

Fig. 2 Analysis of recombinant HEV-3, ratHEV, and batHEV capsid protein derivatives by SDS-PAGE (a) and their reactivity with G117AA4 in Western blot (b). HEV hepatitis E virus, Ctr carboxy-terminal truncated capsid protein, $F 1$ amino-terminal fragment of $\mathrm{Ctr}, F 3$ carboxy-

Sf21 lysate. Again, the blotted protein bands detected by the antibody correlated to the ${ }^{14} \mathrm{C}$-labelled protein bands in the autoradiograph (Fig. 3d). The control experiment with the polyclonal anti-capsid protein rabbit serum showed its clear binding to the cell-free synthesized proteins (Fig. 3e). ${ }^{14} \mathrm{C}$ labelled proteins were detected by autoradiography to qualitatively confirm the proteins (Fig. 3f).

\section{Reactivity of G117-AA4 with cell culture-derived HEV-3}

By immunofluorescence analysis of persistently HEV-3-infected A549 cell cultures, the antibody G117-AA4 generated several foci of green fluorescent cells with intracytoplasmic staining (Fig. 4a). At a higher magnification, green-stained granules were evident, which were mainly localised in the cytoplasm of the cells (cell nuclei are stained blue). No green fluorescence was observed by testing non-infected A549 cells using this antibody. Analysis of the persistently HEV-3-infected cells by Western blotting using the antibody G117-AA4 resulted in a prominent band with an apparent molecular weight of approximately 70 $\mathrm{kDa}$, along with several weak bands of lower molecular weight (Fig. 4b). In the supernatant of the HEV-infected cells, a single band of approximately $80 \mathrm{kDa}$ was evident. No bands were detected using this antibody in non-infected cells or supernatants derived from them. As expected, the cellular marker beta-actin was detected by another specific antibody in infected and noninfected cells with the same intensity, but not in the supernatants derived from them.

\section{Cross-reactivity of mAb G117-AA4 to hare HEV-3 and camel HEV-7 capsid proteins}

Immunofluorescence analysis of Vero B4 cells transfected by eukaryotic expression plasmids confirmed the reactivity of

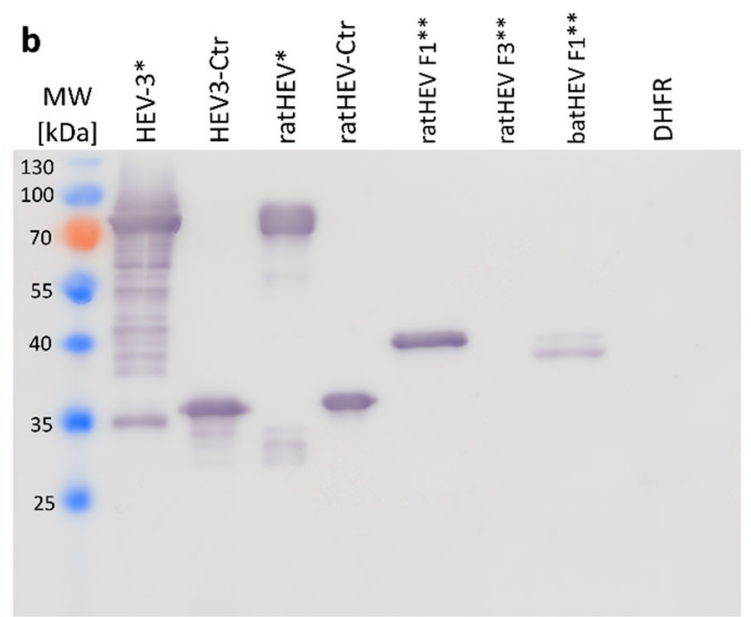

terminal fragment of Ctr, DHFR dihydrofolate reductase. * yeastexpressed full-length proteins (else: E. coli expressed). ** DHFR-fusion proteins

mAb G117-AA4 with capsid proteins of hare HEV-3 and camel HEV-7 (Fig. 5a, c). The analysis of the immunofluorescence slides at higher magnification confirmed the specificity of the reaction by the typical cytoplasmic staining (Fig. $5 b, d)$.

\section{Pepscan-based epitope mapping}

Further refinement of the epitope region was achieved by scanning the full-length ratHEV-F1 sequence in 15-amino acid peptides with an offset of 3 amino acids for antibody binding. Two regions exhibited fluorescence signals higher than 1000 relative fluorescence units (RFU; Fig. 6a). The weaker signal, referring to the sequence QDSADPLPCARSLRY, could be traced back to non-specific interaction of the secondary antibody with the peptide. The sequence exhibiting a stronger fluorescence was further scanned with an amino acid offset of 1 , resulting in the sequence NGEPSVKLYTSVEAA (Fig. 6b, ratHEV capsid protein: 394408 aa) giving the strongest signal. Subsequent replacement of the amino acid residues within this sequence by alanine revealed the positions LYTSV to be essential for proper binding of $\mathrm{mAb}$ G117-AA4 (Figure 6c).

\section{Amino acid sequence comparison and epitope localisation}

The conservation of the suspected epitope region was examined via multiple amino acid sequence alignment (MSA) of different HEV species, genotypes and strains (Table 2). Divergence from the sequence LYTSV, appearing to be essential for mAb G117-AA4 binding in the epitope mapping experiment, was only observed for batHEV Ctr_BS7_GE_2009 (GenBank: JQ001749.1) with one amino acid substitution and for avian HEV (GenBank: AY535004). 
4966

App Microbiol Biotechnol (2021) 105:4957-4973

a

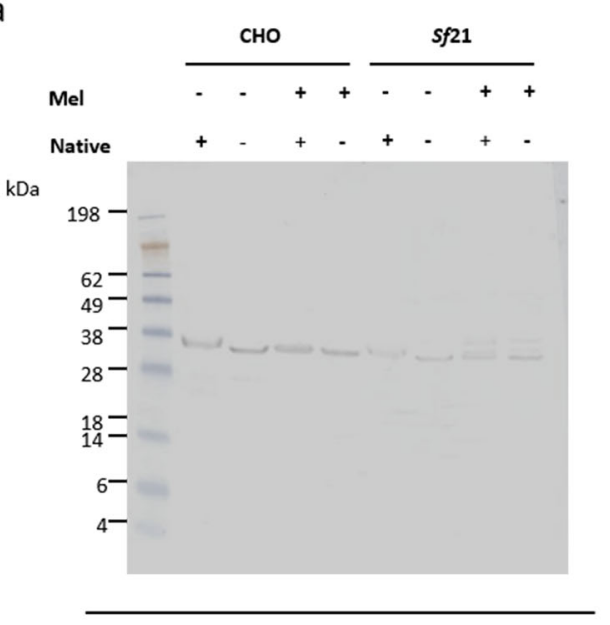

Western Blot

C



RDa

$98-$

$64-$

$50-$

$36-$

$\overline{\text { Western Blot }}$

e

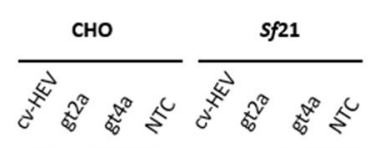

$\mathrm{kDa}$

$98-$

$64-$

$50-$

$36-$

Western Blot b



$\mathrm{kDa}$

$198-$

62

$49^{-}$

$28-$

${ }_{14}^{18}=$

6-

$4^{-}$

Autoradiograph

d

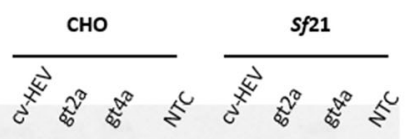

$\mathrm{kDa}$

$98-$

$64-$

$50-$

$36-$

Autoradiograph

f

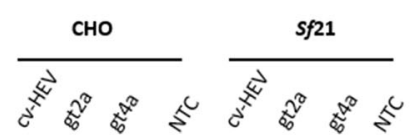

$\mathrm{kDa}$

98-

$64-$

$50-$

$36-$

Autoradiograph

Springer 
4 Fig. 3 Cell-free synthesis of capsid protein derivatives of common vole HEV (cvHEV), HEV-2 (gt2a) and HEV-4 (gt4a), and detection by Western blot analysis. (a) Binding of G117-AA4 antibody to cell-free synthesized cvHEV ORF2-encoded proteins. (b) Autoradiography of ${ }^{14} \mathrm{C}$-labelled cvHEV protein visualized on the blot. Constructs with $(\mathrm{Mel}+)$ and without $(\mathrm{Mel}-)$ the Mel-signal peptide. Proteins were synthesized in $\mathrm{CHO}$ and $\mathrm{Sf2} 1$ lysates. Proteins were blotted in a native (+) and precipitated (-) form. (c) Binding of G117-AA4 antibody to cellfree synthesized cvHEV, HEV-2 (gt2a) and HEV-4 (gt4a). (d) Autoradiography of ${ }^{14} \mathrm{C}$-labelled proteins, initially detected by the monoclonal G117-AA4 antibody, visualized on the blot. (e) Western Blot reactivity of polyclonal rabbit serum with cell-free synthesized cvHEV, HEV-2 (gt2a) and HEV-4 (gt4a). (f) Autoradiography of ${ }^{14} \mathrm{C}$ labelled proteins, initially detected by the polyclonal serum visualized on the blot. NTC, no template control

Structural modelling of the HEV-3 capsid protein indicates localisation of the epitope at an outer pocket of its middle domain (Fig. 7).

\section{Discussion}

In the present study, we generated and characterised a HEV-3capsid protein specific $\mathrm{mAb}$ with strong cross-reactivity to capsid proteins of HEV-1, HEV-2, hare HEV-3, HEV-4, HEV-7, ratHEV, cvHEV and, to a lower extent, also to batHEV capsid protein. Cross-reacting HEV-specific antibodies have also been described previously (He et al. 2007; Kobayashi et al. 2016; Riddell et al. 2000; Schofield et al. 2000, 2003; Takahashi et al. 2008a; Zhang et al. 2005). Despite great genetic diversity, HEV-1-HEV-7 and rabbit $\mathrm{HEV}$, including the human-pathogenic genotypes (HEV-1$\mathrm{HEV}-4$ ), are thought to represent a single serotype (Acharya

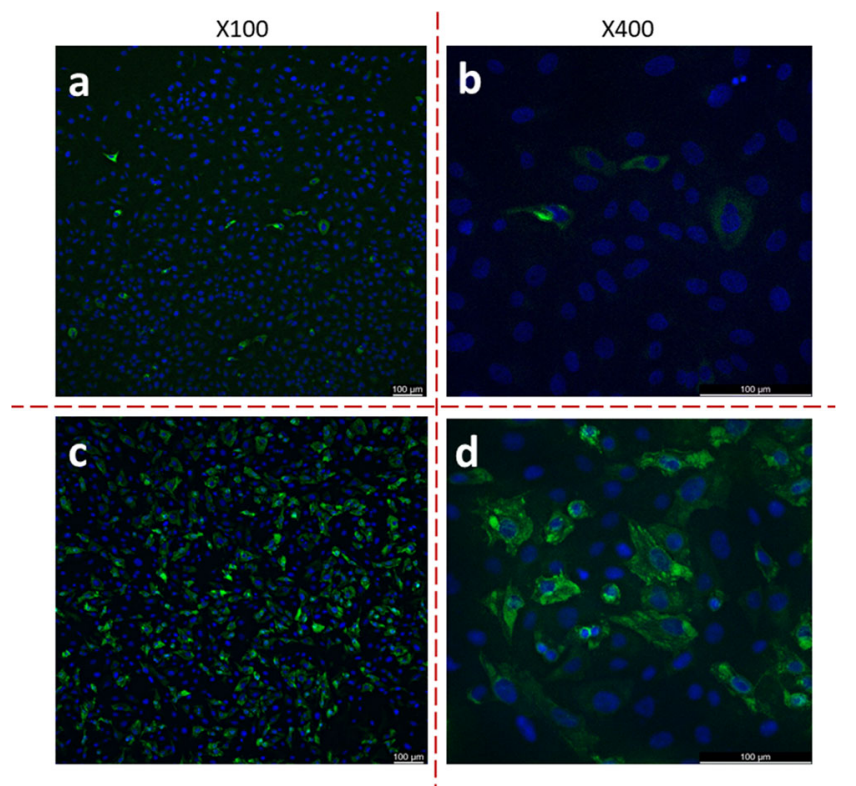

Fig. 5 Immunofluorescence assay-based detection of the reactivity of antibody G117-AA4 with Vero B4 cells transfected with pCG1-derived expression plasmids encoding hare HEV-3 (a, b) and camel HEV-7 (c, d) capsid proteins. The monoclonal antibody was diluted 1:100. The antimouse IgG secondary antibody was Alexa 488-labelled. Slides were counterstained by DAPI. Magnifications are given above the pictures

and Panda 2006; Behloul et al. 2015; Boyer et al. 2012; Lee et al. 2016; Li et al. 2015, 2016; Perez-Gracia et al. 2015; Schlauder and Mushahwar 2001; Smith et al. 2014; Schofield et al. 2003; Wang et al. 2013). Nevertheless, modelling data suggest a slightly different surface exposition of the epitopes, probably accounting for some of the differences in specificity, sensitivity and inter-assay detection observed with


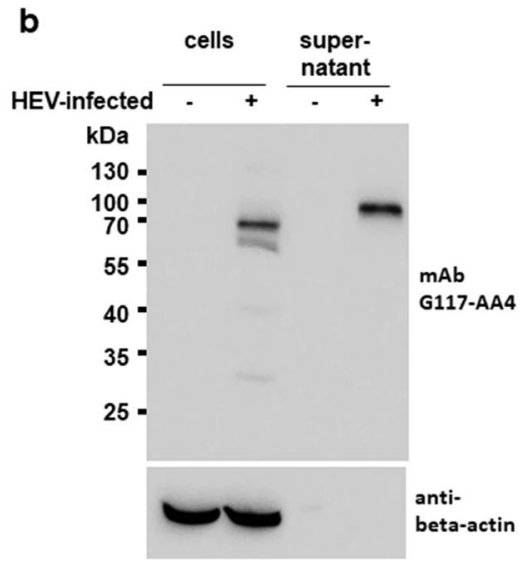

nuclei (DAPI). (b) Western blot analysis of infected and non-infected cells (left) as well as supernatant derived from them (right). The HEVspecific antibody G117-AA4 (upper row) and the anti- $\beta$-actin-specific antibody (lower row) were used. The position of molecular weight markers is indicated
Fig. 4 Analysis of A549 cells persistently infected with the HEV-3 strain 47832c and non-infected A549 cells using the antibody G117-AA4. (a) Immunofluorescence analysis of infected cells (left) and non-infected cells (right). The lower row shows cells at a higher magnification. Green staining, HEV antigen (antibody G117-AA4); blue staining, cell 


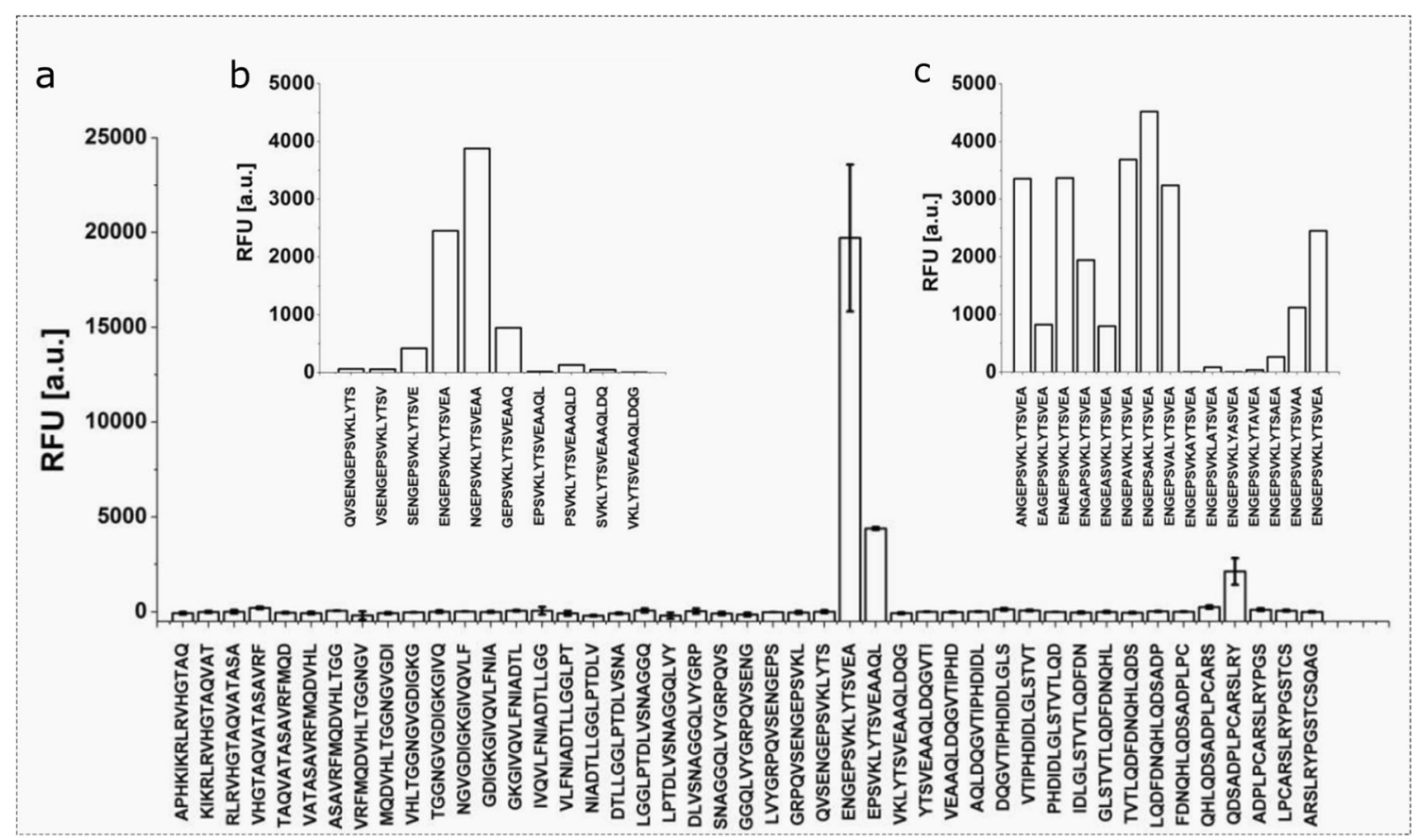

Fig. 6 Epitope mapping of ratHEV-F1 in 15 aa peptides with an offset of 3 aa (a). Two regions exhibited relative fluorescence higher than 1000 RFU (1. ENGE...AAQL and 2. QHLQ...YPGS). The weaker signal (peptide QHLQ...YPGS) could be traced back to non-specific binding

diagnostic antigens derived from different genotypes (Behloul et al. 2015; Drobeniuc et al. 2010).

MAb G117-AA4-related signals of affinity for capsid proteins from HEV-1, HEV-2, HEV-3, HEV-4, ratHEV, batHEV and cvHEV in Western and line blot analysis showed strong cross-reactivity. In addition to the strong cross-reactivity, $\mathrm{mAb}$ G117-AA4 reacted with E. coli-expressed and yeast-expressed HEV proteins and native viral antigen, indicating that the binding occurs independently of posttranslational modification. Immunofluorescence staining of persistently HEV-3-infected cell culture and cells transfected by hare HEV-3 and camel

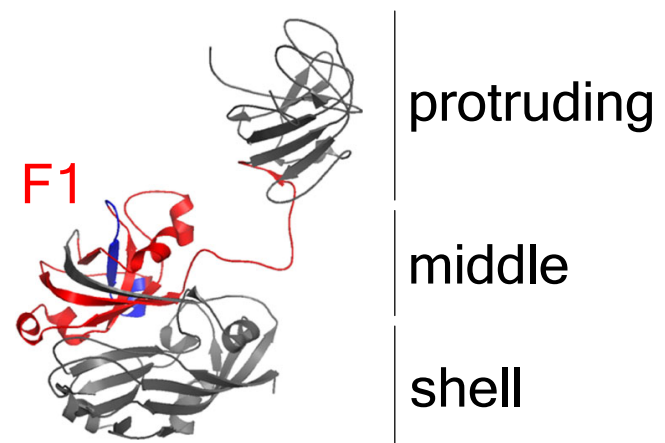

Fig. 7 Epitope localization in HEV-3 capsid protein monomer. Model was calculated with PyMOL based on the crystal structure 2ZTN (Yamashita et al. 2009). Capsid protein domains are named according to Yamashita et al. (2009). Rat HEV-F1 homologous region (red) and NGEPSVKLYTSVEAA-sequence (assumed epitope, dark blue) are highlighted of the secondary antibody. Epitope mapping with an offset of 1 aa (b) and subsequent replacement of single amino acid residues by alanine (c) revealed the sequence LYTSV to be essential for proper binding of mAb G117-AA4

HEV-7 capsid protein expression plasmids revealed mainly cytoplasmic viral proteins (Fig. 4, Fig. 5). The successful staining of native antigen by immunofluorescence indicates at least a partial surface exposition and consequently accessibility of the epitope. Furthermore, the reactivity of the antibody with recombinant and viral antigen in the Western blot analysis suggested a linear epitope as a binding site.

Using a truncated ratHEV capsid protein derivative, the epitope region could be mapped to amino acid residues 316449 by Western blot detection. Additionally, mAb G117-AA4 recognised the analogous batHEV F1 construct in ELISA and Western blot analysis, underlining the cross-reactivity and epitope conservation. Further epitope mapping by Pepscan analysis of ratHEV identified amino acids 394-408 as the binding site, and the alanine scan revealed the sequence LYTSV as an essential binding site. This highly conserved region is located within the scaffolding middle region of the capsid monomer, and protein modelling of the capsid structure shows that this epitope is partially exposed to the surface (Wang et al. 2015). Nevertheless, synergistic effects of antibody binding and epitope accessibility have been reported in competitive studies (Zhang et al. 2005) possibly altering surface exposure of epitopes. Since mAb G117-AA4 successfully detected viral protein by non-denaturating immunofluorescence analysis of persistently infected cell culture, the epitope appears to be accessible at some stages of virion assembly. Also, the release of the virion as a lipid-associated particle has been proposed, modulating epitope accessibility, antibody- 
binding and neutralisation of virus infectivity (Feng and Lemon 2014; Takahashi et al. 2008a, b).

Immunofluorescence analysis using HEV-3 strain 47832cinfected A549 cells and the novel mAb indicated mainly intracytoplasmic staining of cells and granulae typical for HEV infection as shown in previous studies (Johne et al. 2014b; Takahashi et al. 2008b). By Western blot analysis, a prominent band of $70 \mathrm{kDa}$ was detected in the cells and a band of $80 \mathrm{kDa}$ in the supernatant, which correspond to the described $74 \mathrm{kDa}$ non-glycosylated capsid protein and the 82 to $88 \mathrm{kDa}$ glycosylated capsid proteins, respectively (Jameel et al. 1996). In line, glycosylation was found during cell-free synthesis of Mel-signal sequence-harbouring cvHEV, HEV2a and HEV-4a capsid proteins in Sf21 lysate as seen in Fig. 3. Our finding is in line with recently published results, showing that the non-glycosylated capsid protein of HEV is mainly found within cells, whereas glycosylated forms of this protein are actively secreted into the culture supernatant (Yin et al. 2018). These results underline the suitability of the $\mathrm{mAb}$ for HEV cell culture studies.

In conclusion, the novel $\mathrm{mAb}$ represents a useful tool for detecting HEV antigen in infected cells for pathogenicity and transmission studies and might be of high value for future diagnostic applications. The observed cross-reactivity may allow its use with more distantly related members of the genus Orthohepevirus. Further epitope mapping, cross-reactivity studies and structural studies on different HEV capsid proteins are needed to understand the structural basis of the antigenicity of the epitope region.

Supplementary Information The online version contains supplementary material available at https://doi.org/10.1007/s00253-021-11342-7.

Acknowledgements The support of Mathias Schlegel, Philip El-Duah and Jan Felix Drexler and the excellent technical assistance of Kathrin Baumann and Dörte Kaufmann are kindly acknowledged.

Authors' contributions JAS, RJ and RGU conceived and designed the study. BK, JAS, FR, KM, JR, PLT, LC, ATH, JS, FS, HM, AA and MH performed the various experiments. PD, SK, RPB, DB, RR and FS provided essential resources. JS, RR, MHG, SK, RJ and RGU supervised the investigations. RJ and RGU raised funding for the study. BK, JAS, PLT, FR, JR and JS visualized the results of the study. BK, JAS, FR, PLT, JS, $\mathrm{HM}, \mathrm{MH}, \mathrm{VMC}, \mathrm{RJ}$ and RGU wrote the initial draft. All authors read and approved the final version of the manuscript.

Funding Open access funding enabled and organized by Projekt DEAL. This research was funded by the German Federal Institute for Risk Assessment within the German One Health Initiative (GOHI), grant number 1322-686. In addition, the study was supported in part by a grant from the German Federal Ministry of Health with regard to a decision of the German Bundestag by the Federal Government (CHED-project grant No: ZMVI1-2516-AUK-701 / BMG: 321-4471-02/157). The investigations in the laboratory of RGU were supported by the German Center for Infection Research (DZIF, TTU “Emerging Infections").
Data availability The datasets generated during the current study are included in this published article and its supplementary information file and are available from the corresponding author on reasonable request.

\section{Declarations}

Ethical approval The mice were housed and handled in unity with good animal practice as defined by the Federation of European Laboratory Animal Science Associations (FELASA). All animal protocols were approved by local authorities (Landesamt für Umwelt, Gesundheit und Verbraucherschutz (LUGV) Brandenburg, Germany; Permit-Number: 2347-A-34-1-2020).

Conflict of interest The authors declare that they have no conflict of interest.

Open Access This article is licensed under a Creative Commons Attribution 4.0 International License, which permits use, sharing, adaptation, distribution and reproduction in any medium or format, as long as you give appropriate credit to the original author(s) and the source, provide a link to the Creative Commons licence, and indicate if changes were made. The images or other third party material in this article are included in the article's Creative Commons licence, unless indicated otherwise in a credit line to the material. If material is not included in the article's Creative Commons licence and your intended use is not permitted by statutory regulation or exceeds the permitted use, you will need to obtain permission directly from the copyright holder. To view a copy of this licence, visit http://creativecommons.org/licenses/by/4.0/.

\section{References}

Acharya SK, Panda SK (2006) Hepatitis E virus: epidemiology, diagnosis, pathology and prevention. Trop Gastroenterol 27:63-68

Andonov A, Robbins M, Borlang J, Cao J, Hatchette T, Stueck A, Deschambault Y, Murnaghan K, Varga J, Johnston L (2019) Rat hepatitis $\mathrm{E}$ virus linked to severe acute hepatitis in an immunocompetent patient. J Infect Dis 220(6):951-955. https://doi.org/10.1093/ infdis/jiz025

Balayan MS, Andjaparidze AG, Savinskaya SS, Ketiladze ES, Braginsky DM, Savinov AP, Poleschuk VF (1983) Evidence for a virus in nonA, non-B hepatitis transmitted via the fecal-oral route. Intervirology 20:23-31. https://doi.org/10.1159/000149370

Batts W, Yun S, Hedrick R, Winton J (2011) A novel member of the family Hepeviridae from cutthroat trout (Oncorhynchus clarkii). Virus Res 158:116-123. https://doi.org/10.1016/j.virusres.2011.03. 019

Behloul N, Wen J, Dai X, Dong C, Meng J (2015) Antigenic composition and immunoreactivity differences between HEV recombinant capsid proteins generated from different genotypes. Infect Genet Evol 34:211-220. https://doi.org/10.1016/j.meegid.2015.06.026

Berto A, Grierson S, Hakze-van der Honing R, Martelli F, Johne R, Reetz J, Pavio N, Van der Poel WHM, Banks M (2013) Hepatitis E virus in pork liver sausage, France. Emerg Infect Dis 19:264-266

Bodewes R, van der Giessen J, Haagmans BL, Osterhaus ADME, Smits SL (2013) Identification of multiple novel viruses, including a parvovirus and a hepevirus, in feces of red foxes. J Virol 87:77587764. https://doi.org/10.1128/JVI.00568-13

Boyer TD, Manns MP, Sanyal AJ (2012) Zakim and Boyer's hepatology: a textbook of liver disease. Saunders, Philadelphia

Brödel AK, Sonnabend A, Roberts LO, Stech M, Wüstenhagen DA, Kubick S (2013) IRES-mediated translation of membrane proteins 
and glycoproteins in eukaryotic cell-free systems. PLoS One 8(12): e82234. https://doi.org/10.1371/journal.pone.0082234

Brödel AK, Sonnabend A, Kubick S (2014) Cell-free protein expression based on extracts from CHO cells. Biotechnol Bioeng 111(1):2536. https://doi.org/10.1002/bit.25013

Cao D, Meng X-J (2012) Molecular biology and replication of hepatitis E virus. Emerg Microbes Infect 1:e17. https://doi.org/10.1038/emi. 2012.7

Corman VM, Hilgensloh L, Voigt U, Marklewitz M, Siebert U, Drosten C, Drexler JF (2019) Hepatitis E virus infection in European brown hares, Germany, 2007-2014. Emerg Infect Dis 25(6):1233-1235. https://doi.org/10.3201/eid2506.181618

Dremsek P, Wenzel JJ, Johne R, Ziller M, Hofmann J, Groschup MH, Werdermann S, Mohn U, Dorn S, Motz M, Mertens M, Jilg W, Ulrich RG (2012) Seroprevalence study in forestry workers from eastern Germany using novel genotype 3- and rat hepatitis E virusspecific immunoglobulin G ELISAs. Med Microbiol Immunol 201: 189-200. https://doi.org/10.1007/s00430-011-0221-2

Drexler JF, Seelen A, Corman VM, Fumie Tateno A, Cottontail V, Melim Zerbinati R, Gloza-Rausch F, Klose SM, Adu-Sarkodie Y, Oppong SK, Kalko EKV, Osterman A, Rasche A, Adam A, Müller MA, Ulrich RG, Leroy EM, Lukashev AN, Drosten C (2012) Bats worldwide carry hepatitis E virus-related viruses that form a putative novel genus within the family Hepeviridae. J Virol 86:9134-9147. https:// doi.org/10.1128/JVI.00800-12

Drobeniuc J, Meng J, Reuter G, Greene-Montfort T, Khudyakova N, Dimitrova Z, Kamili S, Teo C-G (2010) Serologic assays specific to immunoglobulin $\mathrm{M}$ antibodies against hepatitis $\mathrm{E}$ virus: pangenotypic evaluation of performances. Clin Infect Dis 51:e24 e27. https://doi.org/10.1086/654801

Feng Z, Lemon SM (2014) Peek-a-boo: membrane hijacking and the pathogenesis of viral hepatitis. Trends Microbiol 22:59-64. https:// doi.org/10.1016/j.tim.2013.10.005

Frank R (1992) Spot-synthesis: : an easy technique for the positionally addressable, parallel chemical synthesis on a membrane support. Tetrahedron 48:9217-9232. https://doi.org/10.1016/S00404020(01)85612-X

Green MR, Sambrook J (2012) Molecular cloning, 4th edn. Cold Spring Harbor Laboratory Press, Cold Spring Harbor

Guan D, Li W, Su J, Fang L, Takeda N, Wakita T, Li T-C, Ke C (2013) Asian musk shrew as a reservoir of rat hepatitis E virus, China. Emerg Infect Dis 19:1341-1343. https://doi.org/10.3201/eid1908. 130069

He J, Kuschner RA, Dewar V, Voet P, Asher LV, Vaughn DW (2007) Characterisation of monoclonal antibodies to hepatitis $\mathrm{E}$ virus (HEV) capsid protein and identification of binding activity. J Biomed Sci 14:555-563. https://doi.org/10.1007/s11373-0079172-4

Jameel S, Zafrullah M, Ozdener MH, Panda SK (1996) Expression in animal cells and characterisation of the hepatitis E virus structural proteins. J Virol 70:207-216. https://doi.org/10.1128/JVI.70.1.207216.1996

Johne R, Heckel G, Plenge-Bönig A, Kindler E, Maresch C, Reetz J, Schielke A, Ulrich RG (2010a) Novel hepatitis E virus genotype in Norway rats, Germany. Emerg Infect Dis 16:1452-1455. https://doi.org/10.3201/eid1609.100444

Johne R, Plenge-Bönig A, Hess M, Ulrich RG, Reetz J, Schielke A (2010b) Detection of a novel hepatitis E-like virus in faeces of wild rats using a nested broad-spectrum RT-PCR. J Gen Virol 91:750 758. https://doi.org/10.1099/vir.0.016584-0

Johne R, Dremsek P, Kindler E, Schielke A, Plenge-Bönig A, Gregersen H, Wessels U, Schmidt K, Rietschel W, Groschup MH, Guenther S, Heckel G, Ulrich RG (2012) Rat hepatitis E virus: geographical clustering within Germany and serological detection in wild Norway rats (Rattus norvegicus). Infect Genet Evol 12:947-956. https://doi.org/10.1016/j.meegid.2012.02.021
Johne R, Dremsek P, Reetz J, Heckel G, Hess M, Ulrich RG (2014a) Hepeviridae: an expanding family of vertebrate viruses. Infect Genet Evol 27:212-229. https://doi.org/10.1016/j.meegid.2014.06. 024

Johne R, Reetz J, Ulrich RG, Machnowska P, Sachsenröder J, Nickel P, Hofmann J (2014b) An ORF1-rearranged hepatitis E virus derived from a chronically infected patient efficiently replicates in cell culture. J Viral Hepat 21:447-456. https://doi.org/10.1111/jvh.12157

Johne R, Trojnar E, Filter M, Hofmann J (2016) Thermal Stability of Hepatitis E Virus as Estimated by a Cell Culture Method. Appl Environ Microbiol 82(14):4225-4231. https://doi.org/10.1128/ AEM.00951-16

Khudyakov Y, Kamili S (2011) Serological diagnostics of hepatitis E virus infection. Virus Res 161:84-92. https://doi.org/10.1016/j. virusres.2011.06.006

Kobayashi T, Takahashi M, Tanggis, Mulyanto, Jirintai S, Nagashima S, Nishizawa T, Okamoto H (2016) Characterisation and epitope mapping of monoclonal antibodies raised against rat hepatitis E virus capsid protein: an evaluation of their neutralising activity in a cell culture system. J Virol Methods 233:78-88. https://doi.org/10.1016/ j.jviromet.2016.03.004

Köhler G, Milstein C (1975) Continuous cultures of fused cells secreting antibody of predefined specificity. Nature 256:495-497. https://doi. org/10.1038/256495a0

Krog JS, Breum SØ, Jensen TH, Larsen LE (2013) Hepatitis E virus variant in farmed mink, Denmark. Emerg Infect Dis 19:20282030. https://doi.org/10.3201/eid1912.130614

Lee GH, Tan BH, Teo ECY, Lim SG, Dan YY, Wee A, Aw PPK, Zhu Y, Hibberd ML, Tan CK, Purdy MA (2016) Chronic infection with camelid hepatitis $\mathrm{E}$ virus in a liver transplant recipient who regularly consumes camel meat and milk. Gastroenterology 150(2):355-357. https://doi.org/10.1053/j.gastro.2015.10.048

Li T-C, Yamakawa Y, Suzuki K, Tatsumi M, Razak MA, Uchida T, Takeda N, Miyamura T (1997) Expression and self-assembly of empty virus-like particles of hepatitis E virus. J Virol 71:72077213. https://doi.org/10.1128/JVI.71.10.7207-7213.1997

Li T-C, Suzaki Y, Ami Y, Dhole TN, Miyamura T, Takeda N (2004) Protection of cynomolgus monkeys against HEV infection by oral administration of recombinant hepatitis E virus-like particles. Vaccine 22:370-377. https://doi.org/10.1016/j.vaccine.2003.08.004

Li SW, Zhang J, Li YM, Ou SH, Huang GY, He ZQ, Ge SX, Xian YL, Pang SQ, Ng MH, Xia NS (2005a) A bacterially expressed particulate hepatitis E vaccine: antigenicity, immunogenicity and protectivity on primates. Vaccine 23:2893-2901. https://doi.org/ 10.1016/j.vaccine.2004.11.064

Li T-C, Takeda N, Miyamura T, Matsuura Y, Wang JCY, Engvall H, Hammar L, Xing L, Cheng RH (2005b) Essential elements of the capsid protein for self-assembly into empty virus-like particles of hepatitis E virus. J Virol 79:12999-13006. https://doi.org/10.1128/ JVI.79.20.12999-13006.2005

Li T-C, Yoshimatsu K, Yasuda SP, Arikawa J, Koma T, Kataoka M, Ami Y, Suzaki Y, Le Mai TQ, Hoa NT, Yamashiro T, Hasebe F, Takeda N, Wakita T (2011) Characterisation of self-assembled virus-like particles of rat hepatitis $\mathrm{E}$ virus generated by recombinant baculoviruses. J Gen Virol 92:2830-2837. https://doi.org/10.1099/ vir.0.034835-0

Li W, Guan D, Su J, Takeda N, Wakita T, Li T-C, Ke CW (2013) High prevalence of rat hepatitis $\mathrm{E}$ virus in wild rats in China. Vet Microbiol 165:275-280. https://doi.org/10.1016/j.vetmic.2013.03. 017

Li T-C, Kataoka M, Takahashi K, Yoshizaki S, Kato T, Ishii K, Takeda N, Mishiro S, Wakita T (2015) Generation of hepatitis E virus-like particles of two new genotypes G5 and G6 and comparison of antigenic properties with those of known genotypes. Vet Microbiol 178: 150-157. https://doi.org/10.1016/j.vetmic.2015.04.020 
Li T-C, Zhou X, Yoshizaki S, Ami Y, Suzaki Y, Nakamura T, Takeda N, Wakita T (2016) Production of infectious dromedary camel hepatitis $\mathrm{E}$ virus by a reverse genetic system: potential for zoonotic infection. J Hepatol 65(6):1104-1111. https://doi.org/10.1016/j.jhep.2016.07. 013

Lin J, Karlsson M, Olofson AS, Belak S, Malmsten J, Dalin AM, Widen F, Norder H (2015) High prevalence of hepatitis E virus in Swedish moose-a phylogenetic characterisation and comparison of the virus from different regions. PLoS One 10:e122102. https://doi.org/10. 1371/journal.pone.0122102

Meng XJ, Anderson DA, Arankalle VA, Emerson SU, Harrison TJ, Jameel S, Okamoto H (2012) Hepeviridae. In: King AMQ, Adams MJ, Carstens EB, Lefkowitz EJ (eds) Virus Taxonomy: Ninth Report of the International Committee on Taxonomy of Viruses. Academic Press, London, pp 1021-1028

Mulyanto, Suparyatmo JB, Andayani IGAS, Khalid Takahashi M, Ohnishi H, Jirintai S, Nagashima S, Nishizawa T, Okamoto H (2014) Marked genomic heterogeneity of rat hepatitis E virus strains in Indonesia demonstrated on a full-length genome analysis. Virus Res 179:102-112. https://doi.org/10.1016/j.virusres.2013.10.029

Nagashima S, Takahashi M, Jirintai S, Tanggis Kobayashi T, Nishizawa T, Okamoto H (2014) The membrane on the surface of hepatitis E virus particles is derived from the intracellular membrane and contains trans-Golgi network protein 2. Arch Virol 159:979-991. https://doi.org/10.1007/s00705-013-1912-3

Pavio N, Meng XJ, Doceul V (2015) Zoonotic origin of hepatitis E. Curr Opin Virol 10:34-41. https://doi.org/10.1016/j.coviro.2014.12.006

Perez-Gracia MT, Garcia M, Suay B, Mateos-Lindemann ML (2015) Current knowledge on hepatitis E. J Clin Transl Hepatol 3:117126. https://doi.org/10.14218/JCTH.2015.00009

Purcell RH, Emerson SU (2008) Hepatitis E: an emerging awareness of an old disease. J Hepatol 48:494-503. https://doi.org/10.1016/j. jhep.2007.12.008

Raj VS, Smits SL, Pas SD, Provacia LBV, Moorman-Roest H, Osterhaus ADME, Haagmans BL (2012) Novel hepatitis E virus in ferrets, the Netherlands. Emerg Infect Dis 18:1369-1370. https://doi.org/10. 3201/eid1808.111659

Riddell MA, Li F, Anderson DA (2000) Identification of immunodominant and conformational epitopes in the capsid protein of hepatitis $\mathrm{E}$ virus by using monoclonal antibodies. J Virol 74: 8011-8017. https://doi.org/10.1128/jvi.74.17.8011-8017.2000

Ryll R, Bernstein S, Heuser E, Schlegel M, Dremsek P, Zumpe M, Wolf S, Pépin M, Bajomi D, Müller G, Heiberg A-C, Spahr C, Lang J, Groschup MH, Ansorge H, Freise J, Guenther S, Baert K, Ruiz-Fons F, Pikula J, Knap N, Tsakmakidis I, Dovas C, Zanet S, Imholt C, Heckel G, Johne R, Ulrich RG (2017) Detection of rat hepatitis E virus in wild Norway rats (Rattus norvegicus) and Black rats (Rattus rattus) from 11 European countries. Vet Microbiol 208:58-68. https://doi.org/10.1016/j.vetmic.2017.07.001

Ryll R, Heckel G, Corman V, Drexler URG (2019) Genomic and spatial variability of a European common vole hepevirus. Arch Virol 164(11):2671-2682. https://doi.org/10.1007/s00705-019-04347-1

Sato Y, Sato H, Naka K, Furuya S, Tsukiji H, Kitagawa K, Sonoda Y, Usui T, Sakamoto H, Yoshino S, Shimizu Y, Takahashi M, Nagashima S, Jirintai Nishizawa T, Okamoto H (2011) A nationwide survey of hepatitis $\mathrm{E}$ virus (HEV) infection in wild boars in Japan: identification of boar HEV strains of genotypes 3 and 4 and unrecognised genotypes. Arch Virol 156:1345-1358. https://doi. org/10.1007/s00705-011-0988-x

Schemmerer M, Apelt S, Trojnar E, Ulrich RG, Wenzel JJ, Johne R (2016) Enhanced replication of hepatitis E virus strain $47832 \mathrm{c}$ in an A549-derived subclonal cell line. Viruses. 8(10):267. https:// doi.org/10.3390/v8100267

Schenk JA, Matyssek F, Micheel B (2004) Interleukin 4 increases the antibody response against Rubisco in mice. In Vivo 18:649-652
Schenk JA, Fettke J, Lenz C, Albers K, Mallwitz F, Gajovic-Eichelmann N, Ehrentreich-Förster E, Kusch E, Sellrie F (2012) Secretory leukocyte protease inhibitor (SLPI) might contaminate murine monoclonal antibodies after purification on protein G. J Biotechnol 158: 34-35. https://doi.org/10.1016/j.jbiotec.2011.12.025

Schielke A, Sachs K, Lierz M, Appel B, Jansen A, Johne R (2009) Detection of hepatitis $\mathrm{E}$ virus in wild boars of rural and urban regions in Germany and whole genome characterisation of an endemic strain. Virol J 6:58. https://doi.org/10.1186/1743-422X-6-58

Schlauder GG, Mushahwar IK (2001) Genetic heterogeneity of hepatitis E virus. J Med Virol 65:282-292. https://doi.org/10.1002/jmv.2031

Schlosser J, Eiden M, Vina-Rodriguez A, Fast C, Dremsek P, Lange E, Ulrich RG, Groschup MH (2014) Natural and experimental hepatitis E virus genotype 3-infection in European wild boar is transmissible to domestic pigs. Vet Res 45:121. https://doi.org/10.1186/s13567014-0121-8

Schofield DJ, Glamann J, Emerson SU, Purcell RH (2000) Identification by phage display and characterisation of two neutralising chimpanzee monoclonal antibodies to the hepatitis $\mathrm{E}$ virus capsid protein. $\mathrm{J}$ Virol 74:5548-5555. https://doi.org/10.1128/jvi.74.12.5548-5555. 2000

Schofield DJ, Purcell RH, Nguyen HT, Emerson SU (2003) Monoclonal antibodies that neutralise HEV recognise an antigenic site at the carboxyterminus of an ORF2 protein vaccine. Vaccine 22:257267. https://doi.org/10.1016/j.vaccine.2003.07.008

Scobie L, Dalton HR (2013) Hepatitis E: source and route of infection, clinical manifestations and new developments. J Viral Hepat 20:111. https://doi.org/10.1111/jvh.12024

Shimizu K, Hamaguchi S, Ngo CC, Li T-C, Ando S, Yoshimatsu K, Yasuda SP, Koma T, Isozumi R, Tsuda Y, Fujita H, Pham TT, Le MQ, Dang AD, Nguyen TQ, Yoshida L-M, Ariyoshi K, Arikawa J (2016) Serological evidence of infection with rodent-borne hepatitis E virus HEV-C1 or antigenically related virus in humans. J Vet Med Sci 78:1677-1681. https://doi.org/10.1292/jvms.16-0200

Simanavicius M, Tamosiunas PL, Petraityte-Burneikiene R, Johne R, Ulrich RG, Zvirbliene A, Kucinskaite-Kodze I (2018) Generation in yeast and antigenic characterization of hepatitis E virus capsid protein virus-like particles. Appl Microbiol Biotechnol 102(1): 185-198. https://doi.org/10.1007/s00253-017-8622-9

Smith DB, Simmonds P, Jameel S, Emerson SU, Harrison TJ, Meng X-J, Okamoto H, Van der Poel WHM, Purdy MA (2014) Consensus proposals for classification of the family Hepeviridae. J Gen Virol 95:2223-2232. https://doi.org/10.1099/vir.0.068429-0

Smith DB, Simmonds P, Izopet J, Oliveira-Filho EF, Ulrich RG, Johne R, Koenig M, Jameel S, Harrison TJ, Meng X-J, Okamoto H, Van der Poel WHM, Purdy MA (2016) Proposed reference sequences for hepatitis E virus subtypes. J Gen Virol 97:537-542. https://doi. org/10.1099/jgv.0.000393

Smith DB, Izopet J, Nicot F, Simmonds P, Jameel S, Meng XJ, Norder H, Okamoto H, van der Poel WHM, Reuter G, Purdy MA (2020) Update: proposed reference sequences for subtypes of hepatitis $\mathrm{E}$ virus (species Orthohepevirus A). J Gen Virol 101(7):692-698. https://doi.org/10.1099/jgv.0.001435

Sridhar S, Yip C, Wu S, Cai J, Zhang A, Leung K, Yuen K (2018) Rat hepatitis E virus as cause of persistent hepatitis after liver pransplant. Emerg Infect Dis 24(12):2241-2250. https://doi.org/10.3201/ eid2412.180937

Sridhar S, Yip CCY, Wu S, Chew NFS, Leung KH, Chan JFW, Zhao PS, Chan WM, Poon RWS, Tsoi HW, Cai JP (2021) Transmission of rat hepatitis E virus infection to humans in Hong Kong: A clinical and epidemiological analysis. Hepatology 73(1):10-22. https://doi.org/ 10.1002/hep. 31138

Stech M, Merk H, Schenk JA, Stöcklein WFM, Wüstenhagen DA, Micheel B, Duschl C, Bier FF, Kubick S (2012) Production of functional antibody fragments in a vesicle-based eukaryotic cell- 
free translation system. J Biotechnol 164(2):220-231. https://doi. org/10.1016/j.jbiotec.2012.08.020

Takahashi M, Hoshino Y, Tanaka T, Takahashi H, Nishizawa T, Okamoto H (2008a) Production of monoclonal antibodies against hepatitis $\mathrm{E}$ virus capsid protein and evaluation of their neutralising activity in a cell culture system. Arch Virol 153:657-666. https:// doi.org/10.1007/s00705-008-0045-6

Takahashi M, Yamada K, Hoshino Y, Takahashi H, Ichiyama K, Tanaka T, Okamoto $H$ (2008b) Monoclonal antibodies raised against the ORF3 protein of hepatitis E virus (HEV) can capture HEV particles in culture supernatant and serum but not those in feces. Arch Virol 153:1703-1713. https://doi.org/10.1007/s00705-008-0179-6

Takahashi M, Nishizawa T, Nagashima S, Jirintai S, Kawakami M, Sonoda Y, Suzuki T, Yamamoto S, Shigemoto K, Ashida K, Sato Y, Okamoto H (2014) Molecular characterisation of a novel hepatitis E virus (HEV) strain obtained from a wild boar in Japan that is highly divergent from the previously recognised HEV strains. Virus Res 180:59-69. https://doi.org/10.1016/j.virusres.2013.12.014

Thoring L, Wüstenhagen DA, Borowiak M, Stech M, Sonnabend A, Kubick S (2016) Cell-free systems based on CHO cell lysates: optimisation strategies, synthesis of "difficult-to-express" proteins and future perspectives. PLoS One 11(9):e0163670. https://doi.org/10. 1371/journal.pone. 0163670

Thoring L, Zemella A, Wüstenhagen D, Kubick S (2019) Accelerating the production of druggable targets: Eukaryotic cell-free systems come into focus. Methods Protoc 2(2). https://doi.org/10.3390/ mps2020030

Tsarev S (1997) Recombinant vaccine against hepatitis E: dose response and protection against heterologous challenge. Vaccine 15:1834 1838. https://doi.org/10.1016/S0264-410X(97)00145-X

Walker PJ, Siddell SG, Lefkowitz EJ, Mushegian AR, Dempsey DM, Dutilh BE, Harrach B, Harrison RL, Hendrickson RC, Junglen S, Knowles NJ (2019) Changes to virus taxonomy and the International Code of Virus Classification and Nomenclature ratified by the International Committee on Taxonomy of Viruses (2019). Arch Virol 164(9):2417-2429. https://doi.org/10.1007/s00705019-04306-w

Wang S, Cheng X, Dai X, Dong C, Xu M, Liang J, Dong M, Purdy MA, Meng J (2013) Rabbit and human hepatitis E virus strains belong to a single serotype. Virus Res 176:101-106. https://doi.org/10.1016/j. virusres.2013.05.013

Wang X, Zhao Q, Dang L, Sun Y, Gao J, Liu B, Syed SF, Tao H, Zhang G, Luo J, Zhou EM (2015) Characterization of two novel linear Bcell epitopes in the capsid protein of avian hepatitis E virus (HEV) that are common to avian, swine, and human HEVs. J Virol 89(10): 5491-5501. https://doi.org/10.1128/JVI.00107-15
Wang B, Cai CL, Li B, Zhang W, Zhu Y, Chen WH, Zhuo F, Shi ZL, Yang XL (2017) Detection and characterisation of three zoonotic viruses in wild rodents and shrews from Shenzhen city, China. Virol Sin 32(4):290-297. https://doi.org/10.1007/s12250-017-3973-z

Wolf S, Reetz J, Johne R, Heiberg A-C, Petri S, Kanig H, Ulrich RG (2013) The simultaneous occurrence of human norovirus and hepatitis E virus in a Norway rat (Rattus norvegicus). Arch Virol 158: 1575-1578. https://doi.org/10.1007/s00705-013-1646-2

Woo PCY, Lau SKP, Teng JLL, Tsang AKL, Joseph M, Wong EYM, Tang Y, Sivakumar S, Xie J, Bai R, Wernery R, Wernery U, Yuen K-Y (2014) New hepatitis E virus genotype in camels, the Middle East. Emerg Infect Dis 20:1044-1048. https://doi.org/10.3201/ eid2006.140140

Xing L, Kato K, Li T, Takeda N, Miyamura T, Hammar L, Cheng RH (1999) Recombinant hepatitis E capsid protein self-assembles into a dual-domain $\mathrm{T}=1$ particle presenting native virus epitopes. Virology 265:35-45. https://doi.org/10.1006/viro.1999.0005

Yamashita T, Mori Y, Miyazaki N, Cheng RH, Yoshimura M, Unno H, Shima R, Moriishi K, Tsukihara T, Li TC, Takeda N, Miyamura T, Matsuura Y (2009) Biological and immunological characteristics of hepatitis E virus-like particles based on the crystal structure. Proc Natl Acad Sci U S A 106:12986-12991. https://doi.org/10.1073/ pnas.0903699106

Yin X, Ying D, Lhomme S, Tang Z, Walker CM, Xia N, Zheng Z, Feng Z (2018) Origin, antigenicity, and function of a secreted form of ORF2 in hepatitis E virus infection. Proc Natl Acad Sci U S A 115(18): 4773-4778. https://doi.org/10.1073/pnas.1721345115

Zafrullah M, Ozdener MH, Panda SK, Jameel S (1997) The ORF3 protein of hepatitis $\mathrm{E}$ virus is a phosphoprotein that associates with the cytoskeleton. J Virol 71:9045-9053. https://doi.org/10.1128/JVI. 71.12.9045-9053.1997

Zhang J, Gu Y, Ge SX, Li SW, He ZQ, Huang GY, Zhuang H, Ng MH, Xia NS (2005) Analysis of hepatitis E virus neutralisation sites using monoclonal antibodies directed against a virus capsid protein. Vaccine 23:2881-2892. https://doi.org/10.1016/j.vaccine.2004.11. 065

Zhao M, Li X-J, Tang Z-M, Yang F, Wang S-L, Cai W, Zhang K, Xia NS, Zheng Z-Z (2015) A comprehensive study of neutralising antigenic sites on the hepatitis E virus (HEV) capsid by constructing, clustering, and characterising a tool box. J Biol Chem 290:1991019922. https://doi.org/10.1074/jbc.M1 15.649764

Publisher's note Springer Nature remains neutral with regard to jurisdictional claims in published maps and institutional affiliations. 


\section{Affiliations}

Barbara Kubickova $^{1,2} \cdot$ Jörg A. Schenk ${ }^{3,4} \cdot$ Franziska Ramm $^{5,6} \cdot$ Kornelija Markuškiené $^{1,7} \cdot$ Jochen Reetz $^{8}$. Paul Dremsek ${ }^{1,9}$. Paulius Lukas Tamosiunas ${ }^{7}$ - Laima Cepulyte ${ }^{7} \cdot$ Hoai Anh Trinh ${ }^{5}$. Johannes Scholz ${ }^{8}$. Henry Memczak ${ }^{10}$ - Marc Hovestädt ${ }^{10,11}$ - René Ryll ${ }^{1}$ - Rasa Petraityte-Burneikiene ${ }^{7}$. Victor M. Corman ${ }^{12,13}$. Anika Andersson $^{4,5}$. Dietmar Becher ${ }^{15}$. Martin H. Groschup ${ }^{1,14}$. Stefan Kubick ${ }^{5,6,16}$ • Frank Sellrie ${ }^{3,4}$. Reimar Johne $^{8} \cdot$ Rainer G. Ulrich ${ }^{1,14}$ (I)

1 Institute of Novel and Emerging Infectious Diseases, Friedrich-Loeffler-Institut, Federal Research Institute for Animal Health, 17493 Greifswald-Insel Riems, Germany

2 RECETOX, Faculty of Science, Masaryk University, 62500 Brno, Czech Republic

3 Hybrotec GmbH, 14476 Potsdam, Germany

4 UP Transfer GmbH an der Universität Potsdam, 14469 Potsdam, Germany

5 Branch Bioanalytics and Bioprocesses (IZI-BB), Fraunhofer Institute for Cell Therapy and Immunology (IZI), 14476 Potsdam, Germany

6 Institute of Chemistry and Biochemistry, Freie Universität Berlin, 14195 Berlin, Germany

7 Institute of Biotechnology, Life Sciences Centre, Vilnius University, 02241 Vilnius, Lithuania

8 German Federal Institute for Risk Assessment, 10589 Berlin, Germany
9 Zentrum für Pathobiochemie und Genetik, Medizinische Universität Wien, 1090 Wien, Austria

10 qpa bioanalytics $\mathrm{GmbH}, 10585$ Berlin, Germany

11 Surflay Nanotec, 12489 Berlin, Germany

12 Institute of Virology, Charité - Universitätsmedizin Berlin, 10117 Berlin, Germany

13 Site Berlin, German Center for Infection Research (DZIF), 10117 Berlin, Germany

14 Partner site Hamburg-Lübeck-Borstel-Riems, German Center for Infection Research (DZIF), 17493 Greifswald-Insel Riems, Germany

15 Micromun GmbH, 17489 Greifswald, Germany

16 Faculty of Health Sciences, Joint Faculty of the Brandenburg University of Technology Cottbus-Senftenberg, the Brandenburg Medical School Theodor Fontane and the University of Potsdam, Potsdam, Germany 